Date: 07-12-2021

\title{
Role of anterior insula cortex in context-induced relapse of nicotine-seeking.
}

\author{
Hussein Ghareh ${ }^{* 3}$, Isis Alonso-Lozares ${ }^{* 1}$, Dustin Schetters ${ }^{1}$, Rae J. Herman ${ }^{1}$, Tim S. Heistek ${ }^{2}$, Yvar \\ van Mourik ${ }^{1}$, Philip Jean-Richard-dit-Bressel ${ }^{4}$, Gerald Zernig $^{3}$, Huibert D. Mansvelder ${ }^{2}$, Taco J. de \\ Vries $^{1}$, Nathan J. Marchant ${ }^{1}$
}

${ }^{1}$ Department of Anatomy \& Neurosciences, Amsterdam University Medical Center, $1081 \mathrm{HZ}$, Amsterdam, The Netherlands.

${ }^{2}$ Department of Integrative Neurophysiology, Center for Neurogenomics and Cognitive Research, Amsterdam Neuroscience, Vrije Universiteit, Amsterdam $1081 \mathrm{HV}$, the Netherlands

${ }^{3}$ Department of Psychiatry, Medical University of Innsbruck, Innsbruck 6020, Austria

${ }^{4}$ School of Psychology, University of New South Wales, Sydney, Australia

Corresponding Author: Nathan Marchant (n.marchant@amsterdamumc.nl)

* denotes co-first author

Number of pages: 37

Number of figures: 5

Word counts

Abstract: 241 words

Introduction: 569 words

Results: 1753 words

$$
\text { Discussion: } 1855 \text { words }
$$

Methods: 3349 words 


\section{Abstract}

Tobacco use is the leading cause of preventable death worldwide, and relapse during abstinence remains the key barrier to successful treatment of tobacco addiction. During abstinence, environmental contexts associated with nicotine use can induce craving and contribute to relapse. The insular cortex (IC) is thought to be a critical substrate of nicotine addiction and relapse. However, its specific role in context-induced relapse of nicotine-seeking is not fully known. In this study, we report a novel rodent model of context-induced relapse to nicotine-seeking after punishment-imposed abstinence, which models self-imposed abstinence through increasing negative consequences of excessive drug use. Using the neuronal activity marker Fos we find that the anterior (alC), but not the middle or posterior IC, shows increased activity during context-induced relapse. Combining Fos with retrograde labelling of alC inputs, we show projections to aIC from contralateral aIC and basolateral amygdala exhibit increased activity during context-induced relapse. Next, we used fiber photometry in alC and observed phasic increases in alC activity around nicotine-seeking responses during self-

50 administration, punishment, and the context-induced relapse tests. Next, we used chemogenetic 51 inhibition in both male and female rats to determine whether activity in alC is necessary for context-

52 induced relapse. We found that chemogenetic inhibition of alC decreased context-induced nicotine53 seeking after either punishment- or extinction-imposed abstinence. These findings highlight the critical 54 role nicotine-associated contexts play in promoting relapse, and they show that alC activity is critical for this context-induced relapse following both punishment and extinction imposed abstinence. 
bioRxiv preprint doi: https://doi.org/10.1101/2021.12.08 471717; this version posted December 9,2021 . The copyright holder for this preprint (which was not certified by peer review) is the author/funder, who has granted bioRxiv a license to display the preprint in perpetuity. It is made available under aCC-BY 4.0 International license.

\section{Introduction}

Tobacco use is one of the leading causes of preventable death worldwide. In both abstinent and non-abstinent individuals with a history of nicotine use, exposure to cues associated with nicotine use provokes craving $(1,2)$, which is strongly related to relapse (3). Environmental contexts also play a crucial role in nicotine craving. An environmental context associated with nicotine use retains the ability to reinstate cue-induced nicotine craving after extinction in humans $(4,5)$. Pre-clinical models have been used to study the role of contexts in relapse using the extinction-based context-induced reinstatement (or ABA renewal) model $(6,7)$. One potential limitation of the extinction-based models is that extinction does not capture the motivation for abstinence in humans $(8,9)$. We recently developed a variation of this model in which an alcohol-reinforced response is suppressed by responsecontingent punishment (10). These studies built on prior models using punishment to model the negative consequences of drug use (11-14). We and others have demonstrated context-induced relapse of alcohol, food, and cocaine seeking after punishment-imposed abstinence in an alternative context (15-21). The extent to which this phenomenon translates to context-induced relapse of nicotine-seeking has not yet been demonstrated.

The insular cortex (IC) has been considered a critical neural substrate of nicotine addiction since it was discovered that some human patients with stroke-induced damage to their insula had a higher probability of smoking cessation (22). Subsequent clinical studies found that nicotine dependence is positively correlated with cue-induced activation in the insula $(23,24)$, and there is a negative association between nicotine dependence and insula structural integrity (25). Insula activity is related to the processing of drug cues (26), and cue-induced activity in anterior insula is indicative of relapse vulnerability (27). Both nicotine withdrawal and acute abstinence lead to changes in anterior insula activity, and can also weaken connectivity between the default mode network and salience network at the resting state $(28,29)$. In light of these findings, we focus here on the role of the rodent anterior insula cortex (alC) in context-induced relapse of punished nicotine-seeking.

Here we demonstrate for the first time, in both male and female rats, context-induced relapse of nicotine-seeking after punishment of nicotine taking in an alternative context. Using the neuronal marker of activity Fos (30-32), we show that context-induced relapse of punished nicotine-seeking is associated with increased Fos expression in aIC but not middle or posterior IC. We also found that context-induced relapse was associated with increased Fos in projections to alC from both 
contralateral aIC and ipsilateral basolateral amygdala (BLA). Next, we used calcium imaging with fiber photometry $(33,34)$ to record the activity of alC neurons throughout nicotine self-administration, punishment, and context-induced relapse. We found that alC activity was associated with both nicotine infusion and punishment, and also nicotine seeking during the relapse test. To determine a causal role

91 for activity in alC and context induced relapse, we used chemogenetics (35) to inhibit activity in alC,

92 and found that this decreased context-induced relapse after punishment. Because of potential

93 differences in the neural control of context-induced relapse after punishment or extinction (36), we

94 next tested chemogenetic inhibition of alC after extinction. We also found that this inhibition decreased

95 context-induced reinstatement of nicotine seeking. These data highlight the critical role that nicotine-

96 associated contexts play in promoting relapse, and they show that activity in alC is necessary for this,

97 further highlighting a critical role of this structure in relapse to nicotine use. 


\section{Results}

\section{Exp. 1: Context-induced relapse to nicotine-seeking after punishment-imposed abstinence is} associated with increased Fos expression in alC, and projections from BLA to alC.

Behavioral data: Statistical analysis of the training data (Fig. 1B) revealed a significant Nose-Poke $x$ Session interaction $(F(14,210)=16.1, p<0.001)$, indicating that responses on the active nose-poke increased throughout training compared to inactive nose-pokes. In punishment (Fig. 1C) we observed a significant Nose-poke $x$ Session interaction $(F(6,90)=9.6 ; p<0.001)$, reflecting the decrease in active nose-pokes during punishment. On the final test we returned the rats to either context $B$ (Punishment) or context A (Nicotine) (Fig. 1D). We found a significant main effect of Test Context $(F(1,13)=14.7 ; p<0.01)$, and a Test Context $x$ Nose-poke interaction $(F(1,13)=6.4 ; p<0.05)$. These data show that rats tested in the nicotine context significantly increased nicotine-seeking (active nosepokes) compared to the rats tested in the punishment context.

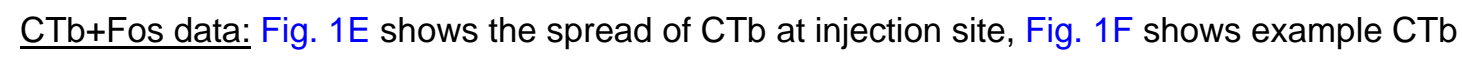
injection in aIC, CTb labelling in pIC and BLA, and CTb+Fos neurons in BLA. Fig. 1G shows the total Fos, CTb, and percentage CTb+Fos neurons in the insula cortex ipsilateral to CTb injection. Using separate one-way ANOVA for each region, we found a significant effect of Test Context for Total Fos in $\operatorname{alC}(F(2,17)=13.1 ; p=0.001)$, $\operatorname{mIC}(F(2,17)=12.6 ; p=0.001)$, and $p I C(F(2,17)=10.1 ; p=0.002)$. Subsequent Tukey post-hoc only revealed a significant difference between rats tested in nicotine versus punishment context for alC $(p=0.025)$. We found no effect of Test Context for the total CTb in $\mathrm{mIC}$ and $\mathrm{plC}(\mathrm{Fs}<1 ; \mathrm{ps}>0.05)$. For percent of $\mathrm{CTb}$ neurons that also express Fos, there was a main effect of Test Context in both $\operatorname{mIC}(F(2,17)=5.3 ; p<0.05)$ and pIC $(F(2,17)=6.5 ; p<0.05)$. However post-hoc analysis revealed no significant difference between the Nicotine and Punishment tested rats.

Fig. $1 \mathrm{H}$ shows the total Fos, CTb, and percentage CTb+Fos neurons in the insula cortex contralateral to CTb injection. Using separate one-way ANOVA for each region, we found a comparable pattern of effects for Total Fos. Specifically, there was a main effect of Test Context in alC $(F(2,17)=14.1 ; p<0.001), \operatorname{mIC}(F(2,17)=8.3 ; p<0.01)$, and pIC $(F(2,17)=21.6 ; p=0.002)$, and subsequent post-hoc revealed a significant difference between rats tested in nicotine or punishment context in alC $(p=0.02)$ as well as pIC $(p=0.003)$, but not $\mathrm{mIC}(p=0.32)$. In all three regions we found no effect of Test Context on total CTb (Fs < 2.5; ps >0.05). For the percent of CTb neurons that 
127 also express Fos, there was a main effect of Test Context in both alC $(F(2,17)=7.4 ; p<0.01)$ and

$128 \mathrm{mIC}(\mathrm{F}(2,17)=4.2 ; \mathrm{p}<0.05)$, but not plC $(\mathrm{F}(2,17)=1.8 ; \mathrm{p}>0.05)$. Post-hoc analysis revealed

129 significant difference between the Nicotine and Punishment tested rats in alC $(p=0.01)$ but not mIC ( $p$

$130=0.3)$. These data show that context-induced relapse of nicotine-seeking is associated with increased

131 activity in the alC neurons that project to the contralateral alC.

132 In Fig. 1 I we show the total Fos, total CTb, and the percentage of CTb neurons that are also Fos

133 positive in the Basolateral Amygdala (BLA) of the ipsilateral hemisphere to the CTb injection. One-way

134 ANOVA revealed a significant effect of Test Context in both anterior $B L A(F(2,17)=21.1 ; p<0.001)$

135 and posterior BLA $(F(2,17)=9.4 ; p<0.001)$. Subsequent Tukey post-hoc revealed a significant

136 difference between rats tested in nicotine or punishment context in aBLA $(p<0.001)$ and $p B L A(p=$

137 0.007). We found no effect of Test Context on total CTb in both aBLA $(F(2,17)<1 ; p>0.05)$ and $p B L A$

$138(F(2,17)<1 ; p>0.05)$. Finally, analysis of the percent of $C T b$ positive neurons that are also Fos

139 positive revealed a significant effect of Test Context in $\operatorname{aBLA}(F(2,17)=13.5 ; p<0.001)$ and $p B L A$

$140(F(2,17)=4.6 ; p<0.05)$. Tukey post-hoc analysis revealed a significant difference between rats tested

141 in nicotine versus punishment context in $\operatorname{aBLA}(p=0.001)$ but not pBLA $(p=0.1)$. In summary, these

142 data show that context-induce relapse of nicotine-seeking is associated with increased activity in BLA,

143 and that there is also selectively increased activity in the aBLA $\rightarrow$ alC pathway. 
A

\section{Behavioural Procedure}

Unilateral alC

Phase 1:

Phase 2:

Phase 3:

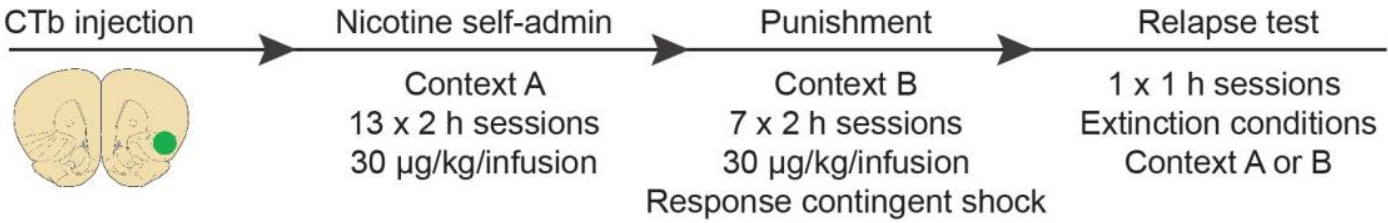

B

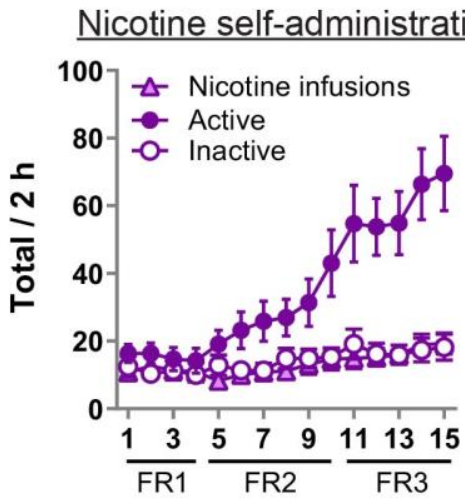

E

CTb injections

No Test Punishment Nicotine

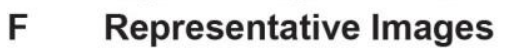

CTb injection BLACTb expression
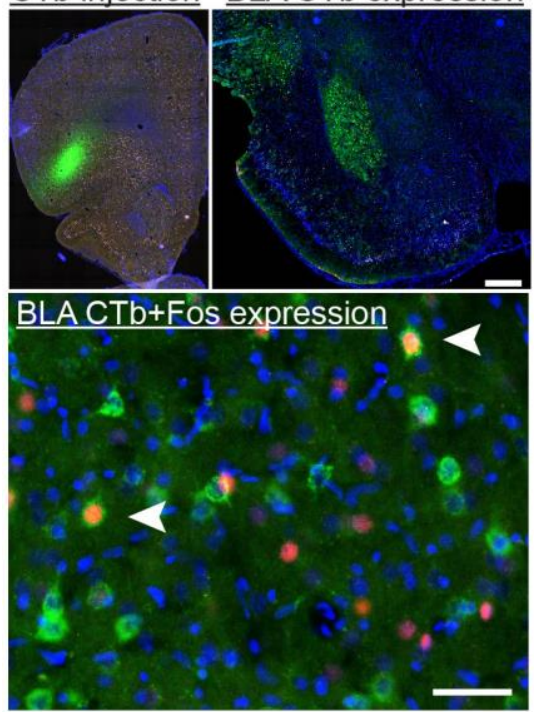

C
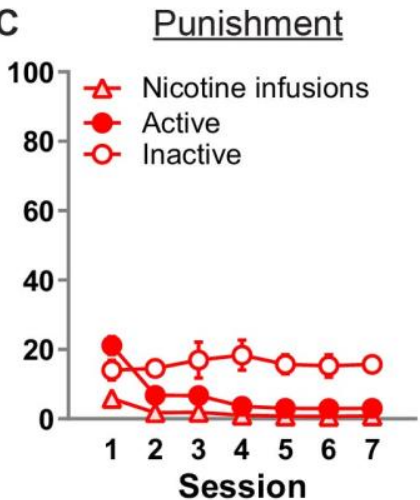

Insula - Ipsilateral to CTb injection

G
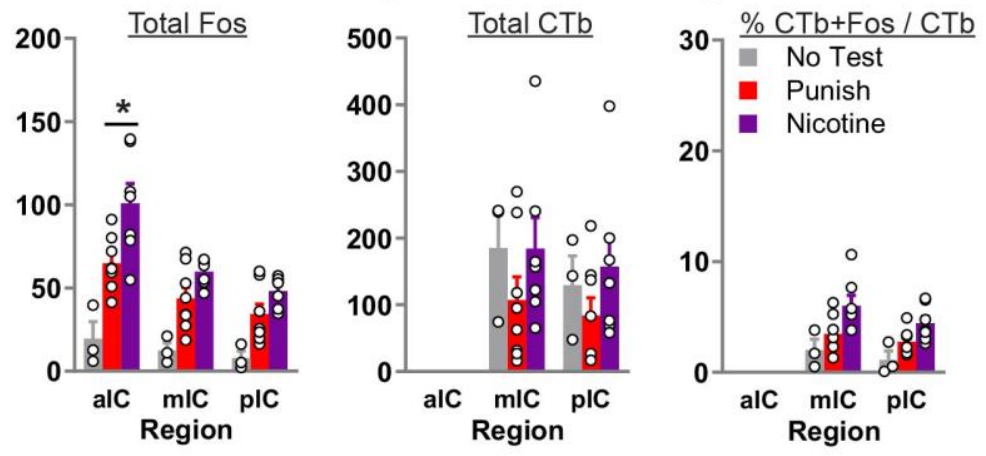

H
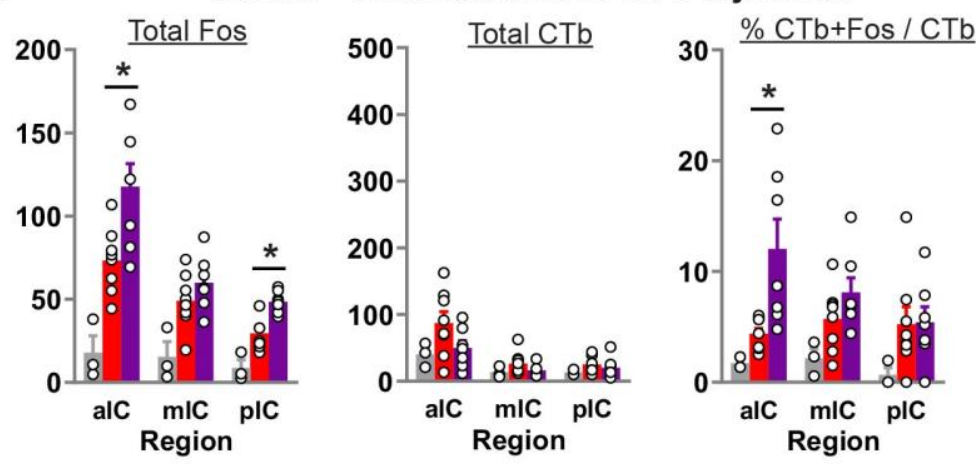

I

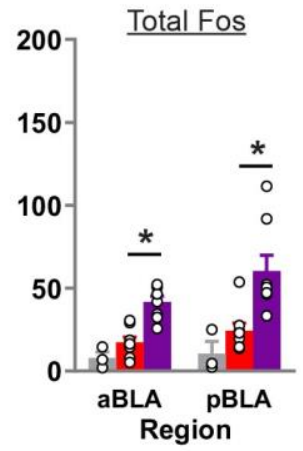

BLA - Ipsilateral to CTb injection
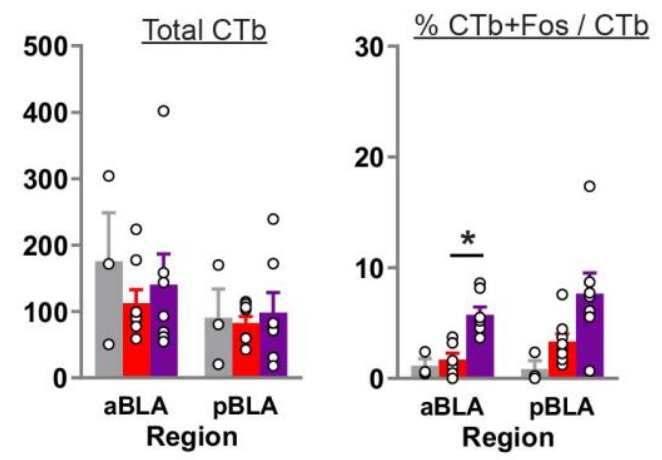
bioRxiv preprint doi: https://doi org/10.1101/2021.12.08.471717: this version posted December 9,2021 . The copyright holder for this preprint (which was not certified by peer review) is the author/funder, who has granted bioRxiv a license to display the preprint in perpetuity. It is made available under aCC-BY 4.0 International license.

145 Figure 1. Context-induced relapse of punished nicotine-seeking is associated with selective activation

146 of $B L A \rightarrow a l C$ and contralateral alC $\rightarrow$ alC projections. (A) Outline of the experimental procedure $(\mathrm{n}=$

14719 female). (B, C, D) Mean \pm sem active and inactive nose-pokes, and nicotine infusions, during

148 nicotine self-administration in context A (B), punishment in context B (C), and the context-induced

149 nicotine-relapse test in context B or A (D). (E) Representative plots of the spread of CTb injections for

150 the three groups. (F) Representative images of CTb injection in alC, and CTb+Fos in BLA. (G, H, I)

151 Data are mean \pm SEM number of Fos or CTb neurons per $\mathrm{mm}^{2}$, and percentage Ctb + Fos neurons, in

152 the IC hemisphere ipsilateral to CTb injection $(\mathbf{G})$, IC hemisphere contralateral to the CTb injection $(\mathbf{H})$,

153 or BLA ipsilateral to the CTb injection (I). * $\mathrm{p}<0.05$; alC, anterior insula cortex; $\mathrm{mIC}$, middle insula

154 cortex; pIC, posterior insula cortex; BLA, Basolateral Amygdala; FR, fixed-ratio. 
bioRxiv preprint doi: https://doi.org/10.1101/2021.12.08.471717: this version posted December 9,2021 . The copyright holder for this preprint (which was not certified by peer review) is the author/funder, who has granted bioRxiv a license to display the preprint in perpetuity. It is made available under aCC-BY 4.0 International license.

159

\section{Exp. 2: Real-time neuronal activity in alC encodes nicotine-seeking responses across nicotine} self-administration, punishment, and context-induced relapse.

We examined real-time population-level alC principal neuron calcium ( $\mathrm{Ca} 2+)$ transients throughout the entire task (Fig. 2A). We used AAV encoding jGCaMP7f under control of the hSyn1 promoter to express the Ca2+ sensor jGCaMP7f (37) in alC. Fluorescence was measured via an optic fiber cannula implanted in alC (Fig. 2B). We analyzed Ca2+ transients around nosepokes using 95\% confidence intervals with a consecutive threshold of $0.25 \mathrm{~s}(38)$.

Behavioral data: Repeated measures ANOVA on the self-administration data (Fig. 2C) revealed a significant effect of Nose-Poke $(F(1,5)=12.8, p<0.05)$. In punishment (Fig. 2D) repeated measures ANOVA revealed no effect of Nose-Poke $(F(1,5)=1.0, p>0.05)$. On the final test we returned the rats to context A (Nicotine) over two test sessions in consecutive days (Fig. 2E). We found an overall effect of Nose-Poke $(F(1,5)=15.8 ; p<0.01)$ reflecting greater responses on the active nose-poke compared to the inactive nose-poke in these test sessions.

Nicotine self-administration photometry data (Fig. 2F): In self-administration, we found that alC shows significant increased excitatory $\mathrm{Ca} 2+$ transients after nose-pokes, suggesting a general role of alC for encoding response-outcome contingencies. Response-generated nicotine infusions (paired with a CS), exhibited a sustained robust biphasic excitatory Ca2+ transient. Importantly we found a significant difference between the reinforced and non-reinforced active nose-poke events, indicating increased activity in alC specifically related to the nicotine-associated cue and nicotine infusion. Surprisingly, we also found that there was increased excitatory Ca2+ transients, relative to baseline, prior to the nose-poke for the two types of active nose-pokes (reinforced, or non-reinforced), but not inactive nose-poke. Direct comparisons between the events, using permutation tests, also revealed a significant difference between the reinforced active nose-poke and inactive nose-poke.

\section{Punishment photometry data (Fig. 2G): In punishment we again found that alC shows excitatory} transients after all nose-pokes. We found that active nose-pokes that resulted in punishment caused a significantly greater sustained excitatory $\mathrm{Ca} 2+$ transient compared to the other outcomes (nicotine infusion, nothing). Moreover, the pattern of activity to the non-punished nicotine infusion changed compared to self-administration, because there was no longer a significant difference between reinforced and non-reinforced active nose-pokes. Another interesting observation is that again, like 
189 self-administration, we found a significant increase in alC activity in the lead up to active but not

190 inactive nose-pokes. There was a significant increase relative to baseline for the three types of active

191 nose-pokes (Punished, Nicotine infusions, non-reinforced), but there was no such increase prior to the

192 inactive nose-pokes. Direct comparison between the events using permutations tests revealed a

193 significant difference between the inactive nose-poke and both nicotine infusion and non-reinforced

194 active nose-pokes, but not the punished nose-poke.

195 Context-induced relapse photometry data (Fig. 2H): In the final two sessions we tested the rats in

196 the original training context (context A) under extinction conditions over two consecutive days. We

197 found significant excitatory $\mathrm{Ca} 2+$ transients in alC, relative to baseline, after all nose-pokes. Like the

198 prior phases, there was also a significant increase in activity prior to active but not inactive nose-

199 pokes. There were no significant differences between active nose-pokes that elicited the nicotine-

200 associated cue versus those that did not, suggesting differential activity observed in previous phases

201 encoded the reinforcing and punishing outcomes (nicotine, shock), which were absent in the final test. 
A

\begin{tabular}{|c|c|c|c|}
\hline $\begin{array}{l}\text { AAV injection } \\
+ \text { Fiber implant }\end{array}$ & $\begin{array}{c}\text { Phase 1: } \\
\text { Nicotine self-admin }\end{array}$ & $\begin{array}{l}\text { Phase 2: } \\
\text { Punishment }\end{array}$ & $\begin{array}{l}\text { Phase 3: } \\
\text { Relapse test }\end{array}$ \\
\hline jGCaMP7f & $\begin{array}{c}\text { Context A } \\
18 \times 1 \mathrm{~h} \text { sessions } \\
30 \mu \mathrm{g} / \mathrm{kg} / \text { infusion }\end{array}$ & $\begin{array}{c}\text { Context B } \\
4-10 \times 1 \mathrm{~h} \text { sessions } \\
30 \mu \mathrm{g} / \mathrm{kg} / \text { infusion }\end{array}$ & $\begin{array}{c}\text { Context } A \\
2 \times 1 \text { h sessions over } 2 \text { days }\end{array}$ \\
\hline
\end{tabular}

Response contingent shock

B

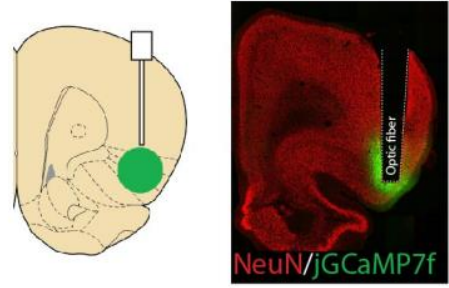

C Nicotine self-administration

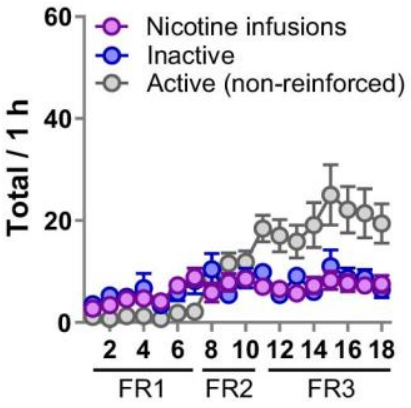

F Nicotine self-administration
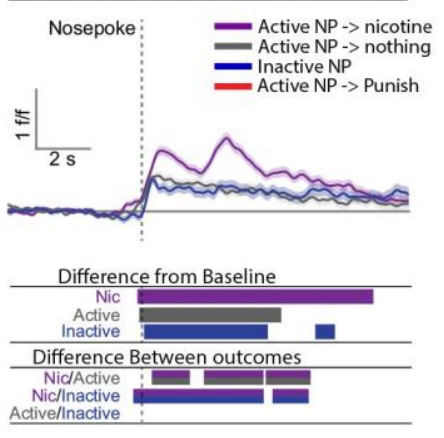

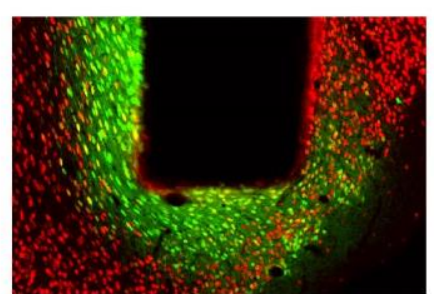

Behaviour

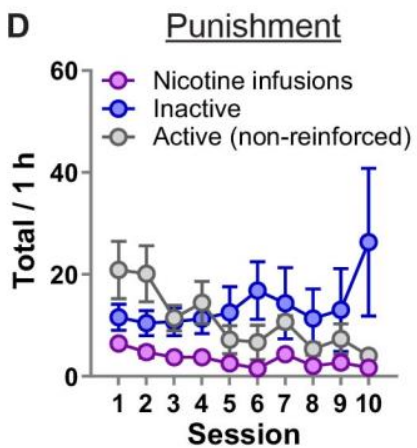

Photometry in alC

G Punishment
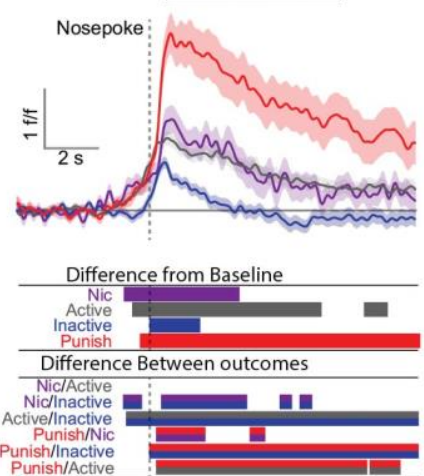

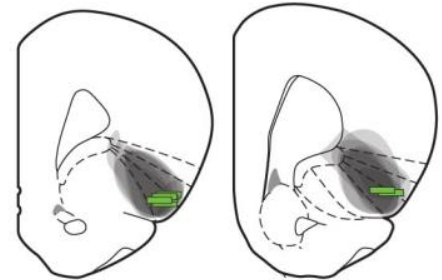

\section{E \\ $\underline{\text { Relapse tests }}$}

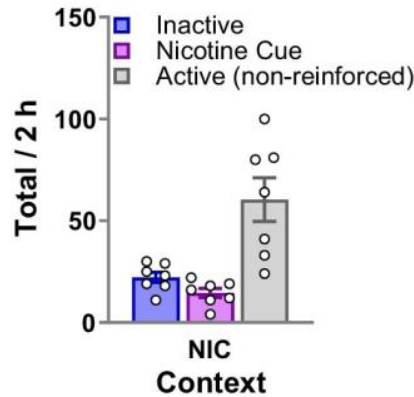

H Relapse tests
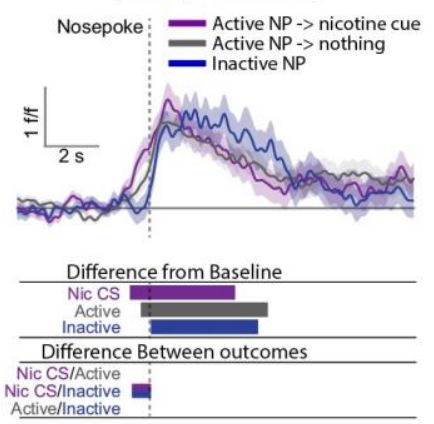

Figure 2. Photometry reveals nicotine and punishment-associated activity in alC. (A) Outline of the

204 experimental procedure ( $n=7$ female). (B) Representative images of jGCaMP7f expression and fiber implant in alC. (C, D, E) Mean \pm sem nicotine infusions, inactive nose-pokes, and non-reinforced active nose-pokes during nicotine self-administration in context $A$ (C), punishment in context B (D), and the context-induced nicotine-seeking tests $(E)$. (E). (F) Ca2+ traces around the nose-poke in alC self-

208 administration in context A (Reinforced active (Nic): $n=751$; Non-reinforced active: $n=838$; Inactive: $\mathrm{n}=588) .(\mathbf{G}) \mathrm{Ca} 2+$ traces around the nose-poke in alC during punishment in context $\mathrm{B}$ (Reinforced

210 active (Nic): $n=89$; Non-reinforced active: $n=366$; Inactive: $n=318$; Punish: $n=137$ ). (H) Ca2+

211 traces around the nose-poke in alC during context-induced relapse test in context A (Active + Nic CS: 
$212 \mathrm{n}=95$; Active non-reinforced: $\mathrm{n}=187$; Inactive: $\mathrm{n}=80$ ). For all photometry traces, bars at bottom of

213 graph indicate significant deviations from baseline $(d F / F \neq 0)$, or significant differences between the

214 specific events (Nicotine infusion, non-reinforced active nose-poke, inactive nose-poke, Punishment,

215 or Nicotine CS), determined via bootstrapped confidence intervals $(95 \% \mathrm{Cl})$, and permutation tests

216 with alpha 0.008 and 0.01 for comparisons between punishment sessions, and self-administration and

217 tests respectively. Vertical dashed line indicates nose-poke, horizontal line indicates baseline $(\mathrm{dF} / \mathrm{F}=$

218 0). 
bioRxiv preprint doi: https://doi org/10.1101/2021.12.08.471717; this version posted December 9, 2021. The copyright holder for this preprint (which was not certified by peer review) is the author/funder, who has granted bioRxiv a license to display the preprint in perpetuity. It is made available under aCC-BY 4.0 International license.

\section{$220 \quad 52+$}

221 Figure 3. Validation of chemogenetic inhibition of alC neurons expressing hM4Di by clozapine. (A)

222 shows the virus injection location. (B) shows example trace of inward current demonstrating clear

223 clozapine-induced hyperpolarization of the hM4Di expressing neurons. (C) shows the average

224 hyperpolarization induced by clozapine for the $n=6$ neurons recorded (left) and the mean

225 hyperpolarization (right) for these neurons. 


\section{Exp. 4: Chemogenetic inhibition of alC decreases context-induced relapse of punished}

\section{8 nicotine-seeking.}

229 Fig. 4B shows nicotine self-administration in context A. We observed a significant Nose-Poke $\mathrm{x}$

230 Session interaction $(F(12,288)=13.4, p<0.001)$, with responses on the active nose-poke increasing

231 throughout training compared to inactive nose-pokes. Fig. 4C shows nicotine self-administration during

232 punishment in context B. We observed a significant Nose-Poke $x$ Session interaction $(F(5,120)=7.1$,

$233 \mathrm{p}<0.001$ ), with responses on the active nose-poke decreasing throughout punishment compared to

234 inactive nose-pokes. Fig. 4D shows nicotine-seeking during the relapse tests. We observed a

235 significant Group $\times$ Nose-poke interaction $(F(1,24)=13.2 ; p=0.001)$, and a Context $\times$ Group $\times$ Nose-

236 poke interaction $(F(1,24)=11.6 ; p=0.001)$. We observed no overall effect of $\operatorname{Sex}(F(1,24)=4.0 ; p>$

237 0.05). Moreover, we found no Sex $x$ Group $x$ Nose-poke interaction $(F(1,24)=2.5 ; p>0.05)$, nor Sex $x$

238 Context $x$ Group $x$ Nose-poke interaction $(F(1,24)=3.6 ; p>0.05)$. These results show that

239 chemogenetic inhibition of alC significantly decreases context-induced relapse of nicotine-seeking

240 after punishment, in both male and female rats. 


\begin{tabular}{|c|c|c|c|}
\hline AAV injections & $\begin{array}{c}\text { Phase 1: } \\
\text { Nicotine self-admin }\end{array}$ & $\begin{array}{l}\text { Phase 2: } \\
\text { Punishment }\end{array}$ & $\begin{array}{l}\text { Phase 3: } \\
\text { Relapse test }\end{array}$ \\
\hline GFP or hM4Di & $\begin{array}{c}\text { Context A } \\
13 \times 2 \mathrm{~h} \text { sessions } \\
30 \mu \mathrm{g} / \mathrm{kg} / \text { infusion }\end{array}$ & $\begin{array}{c}\text { Context B } \\
6 \times 2 \mathrm{~h} \text { sessions } \\
30 \mu \mathrm{g} / \mathrm{kg} / \text { infusion } \\
\text { Response contingent shock }\end{array}$ & $\begin{array}{c}2 \times 1 \mathrm{~h} \text { sessions over } 2 \text { days } \\
\text { Extinction conditions } \\
0.3 \mathrm{mg} / \mathrm{kg} \mathrm{CLZ} 30 \mathrm{~min} \text { prior }\end{array}$ \\
\hline
\end{tabular}

B Nicotine self-administration C

Punishment

D

Relapse tests
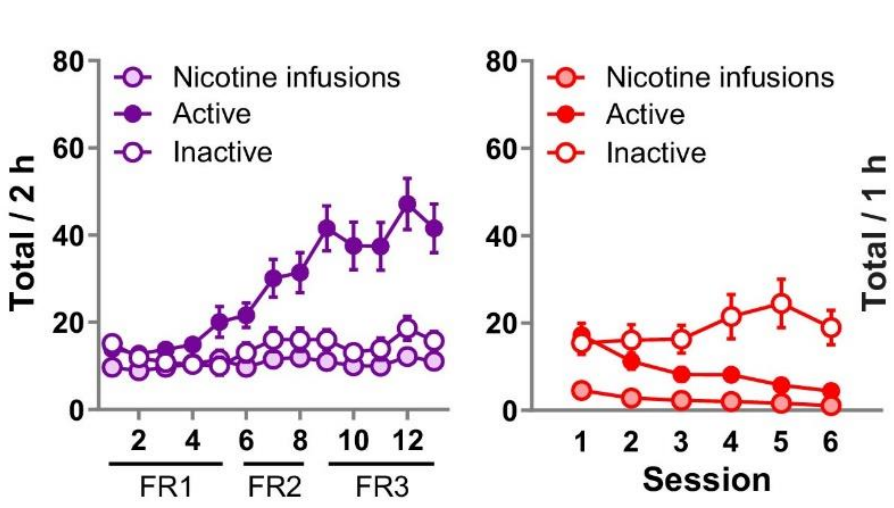

Context B

Context A

$\mathrm{E}$

GFP and hM4Di expression
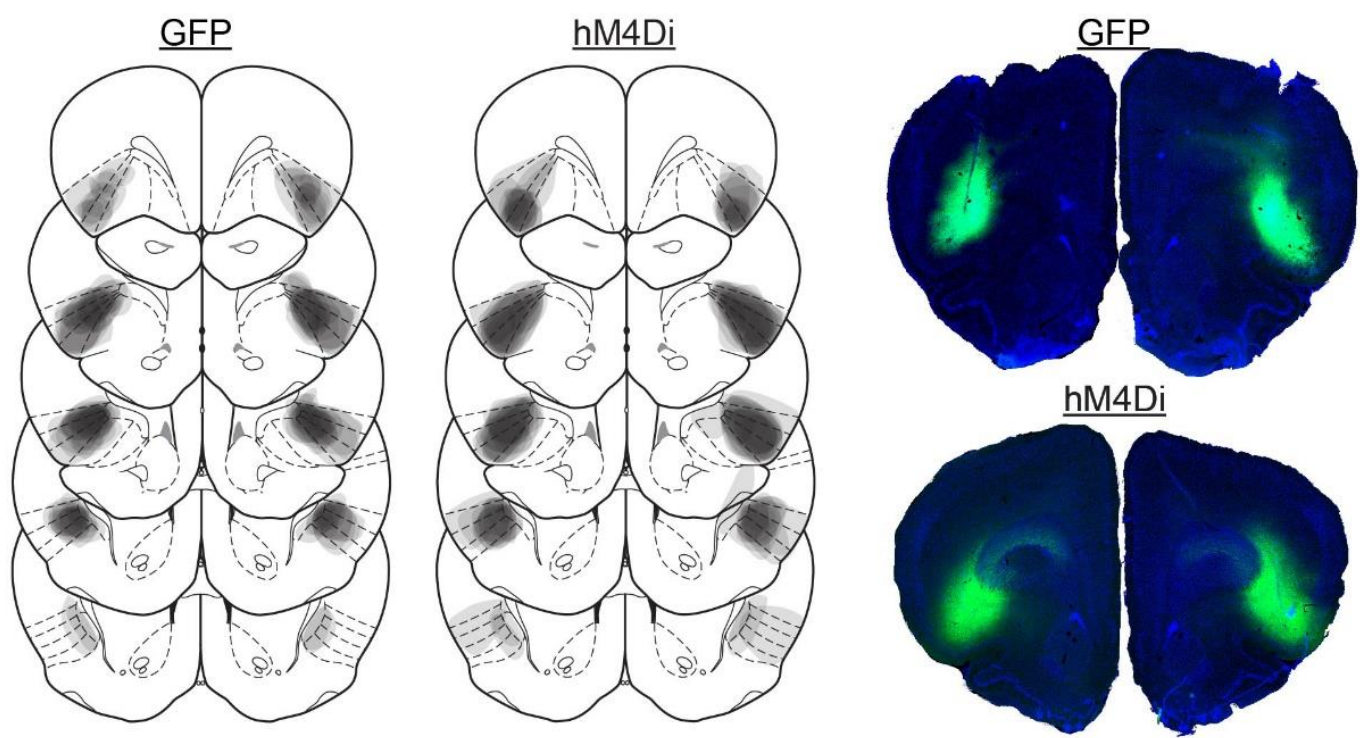

Figure 4. Effect of chemogenetic inhibition of alC on context-induced relapse of punished nicotineseeking. (A) Outline of the experimental procedure $(n=15$ female, 13 male). (B) Mean \pm sem nicotine

246 infusions, active, inactive nose-pokes during nicotine self-administration in context A. (C) Mean \pm sem

247 nicotine infusions, active, inactive nose-pokes during punishment in context B. (D) Mean \pm sem nose-

248 pokes during the context-induced relapse tests. Individual data also plotted, triangles $=$ female, circles

249 = male. (E) Representative plots of the spread of GFP (left) and hM4Di (middle) in alC of rats in

250 experiment 4. Right top shows an example section of a rat showing GFP expression in alC, and right

251 bottom shows an example of hM4Di expression. CLZ, Clozapine; FR, fixed-ratio. 


\section{Exp. 5: Chemogenetic inhibition of alC decreases context-induced relapse of extinguished}

\section{3 nicotine-seeking.}

254 Fig. 5B shows nicotine self-administration in context A. We observed a significant Nose-Poke $x$ 255 Session interaction $(F(12,324)=12.3, p<0.001)$, indicating that responses on the active nose-poke

256 increased throughout training compared to inactive nose-pokes. Fig. 5C shows nicotine-seeking during

257 extinction in context B. We observed a significant effect of Session $(F(7,189)=14.0 ; p<0.001)$, and

258 Nose-Poke $(F(1,27)=15.6 ; p<0.001)$, but no Session $\times$ Nose-poke interaction $(F(7,189)=1.5 ; p>$

259 0.05); both the active and inactive nose-poke decreased throughout extinction. Fig. 5D shows

260 nicotine-seeking during the relapse tests. We observed a significant Group x Nose-poke interaction

$261(F(1,27)=8.5 ; p<0.01)$, as well as a Context $\times$ Group $\times$ Nose-poke interaction $(F(1,27)=11.3 ; p<$

262 0.01). We observed no overall effect of $\operatorname{Sex}(F(1,27)=1.6 ; p>0.05)$, and no Sex $x$ Group $x$ Nose-

263 poke interaction $(F(1,27)=1.1 ; p>0.05)$, nor Sex $x$ Context $x$ Group $x$ Nose-poke interaction $(F(1,24)$

$264<1 ; p>0.05)$. These results show that chemogenetic inhibition of alC significantly decreases context-

265 induced relapse of nicotine-seeking after extinction, in both male and female rats.

266

267 


\begin{tabular}{|c|c|c|c|}
\hline AAV injections & $\begin{array}{c}\text { Phase 1: } \\
\text { Nicotine self-admin }\end{array}$ & $\begin{array}{l}\text { Phase 2: } \\
\text { Extinction }\end{array}$ & $\begin{array}{l}\text { Phase 3: } \\
\text { Relapse test }\end{array}$ \\
\hline GFP or hM4Di & $\begin{array}{c}\text { Context A } \\
13 \times 2 \mathrm{~h} \text { sessions } \\
30 \mu \mathrm{g} / \mathrm{kg} / \text { infusion }\end{array}$ & $\begin{array}{c}\text { Context B } \\
8 \times 2 \text { h sessions } \\
\text { Saline infusion }\end{array}$ & $\begin{array}{c}2 \times 1 \mathrm{~h} \text { sessions over } 2 \text { days } \\
\text { Extinction conditions } \\
0.3 \mathrm{mg} / \mathrm{kg} \mathrm{CLZ} 30 \mathrm{~min} \text { prior }\end{array}$ \\
\hline
\end{tabular}

B Nicotine self-administration C

D Relapse tests

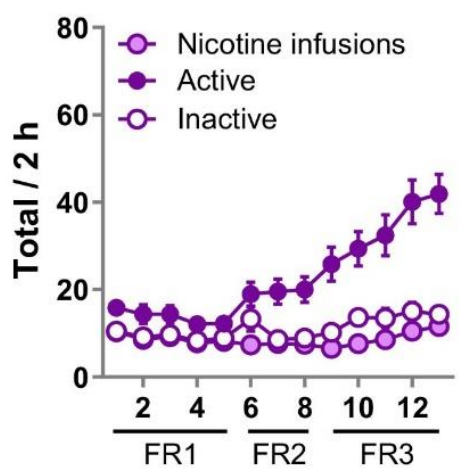

$E$
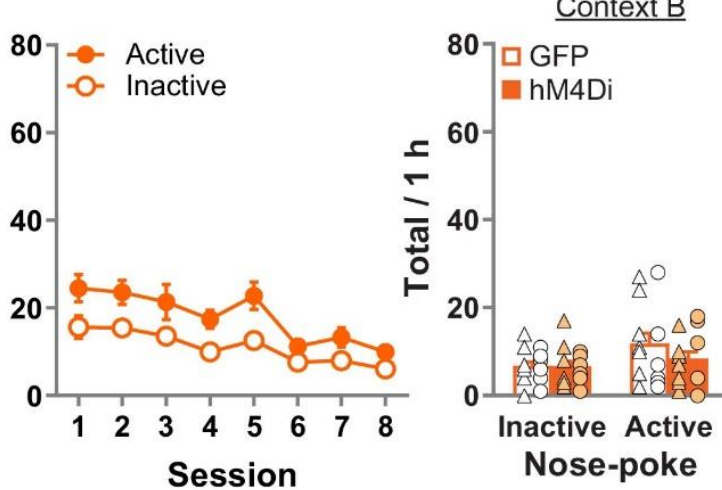

Context A

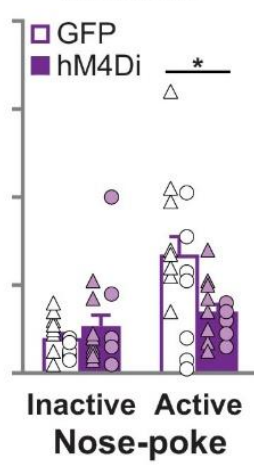

GFP and hM4Di expression

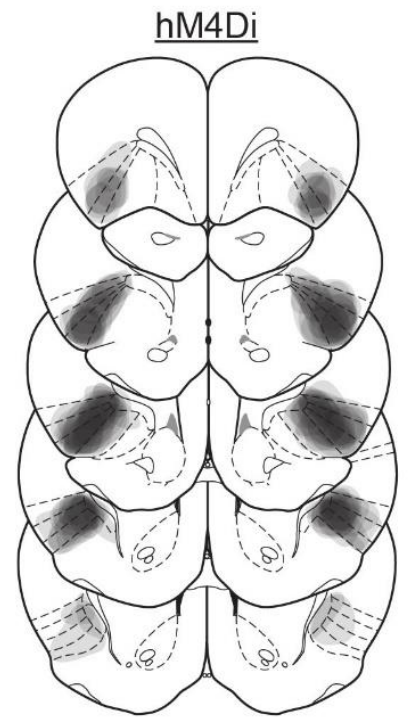

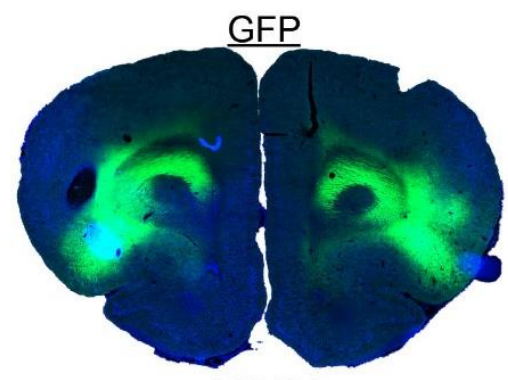

hM4Di

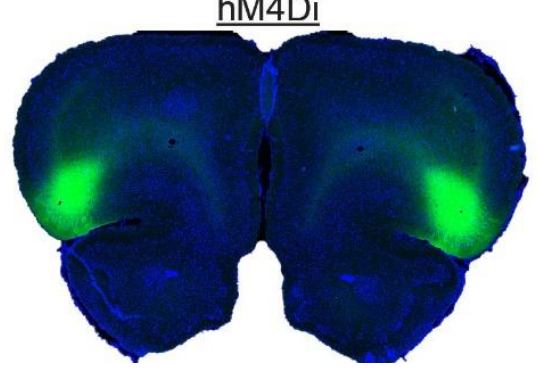

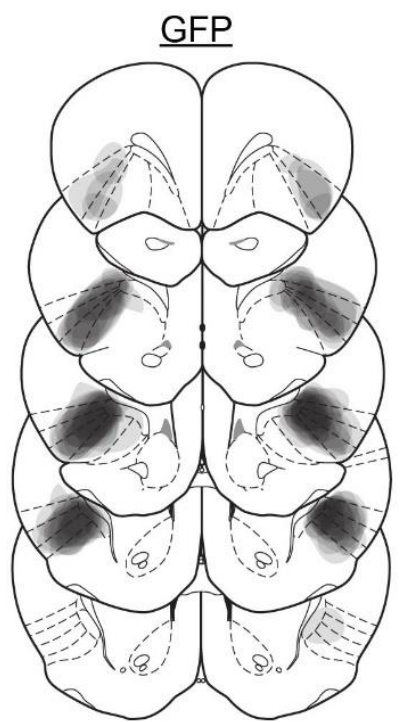

Figure 5. Effect of chemogenetic inhibition of alC on context-induced relapse of extinguished nicotine-seeking. (A) Outline of the experimental procedure $(n=18$ female, 13 male). (B) Mean \pm sem

271 nicotine infusions, active, inactive nose-pokes during nicotine self-administration in context $\mathrm{A}$. (C)

272 Mean \pm sem active, inactive nose-pokes during extinction in context B. (D) Mean \pm sem nose-pokes

273 during the context-induced relapse tests. Individual data also plotted, triangles $=$ female, circles $=$

274 male. (E) Representative plots of the spread of GFP (left) and hM4Di (middle) in alC of rats in

275 experiment 5. Right top shows an example section of a rat showing GFP expression in alC, and right bottom shows an example of hM4Di expression. CLZ, Clozapine; FR, fixed-ratio. 
bioRxiv preprint doi: https://doi.org/10.1101/2021.12.08 471717; this version posted December 9,2021 . The copyright holder for this preprint (which was not certified by peer review) is the author/funder, who has granted bioRxiv a license to display the preprint in perpetuity. It is made available under aCC-BY 4.0 International license.

\section{Discussion}

In this study, we describe a novel rodent model of context-induced relapse to nicotine-seeking after

279 punishment-imposed abstinence. We found that this form of relapse is associated with increased Fos

280 expression in alC, but not $\mathrm{mIC}$ or pIC, as well as BLA. Using retrograde tracing from alC, we also

281 show that inputs from contralateral aIC and ipsilateral anterior BLA are also activated during context-

282 induced relapse of nicotine-seeking. Using fiber photometry, we found that nicotine infusions during

283 self-administration elicited phasic increases in alC activity. During punishment, phasic increases in alC

284 activity was significantly greater for the punishment outcome compared to nicotine infusion and non-

285 reinforced responses. During the final tests we found increased activity associated with each response

286 type. Interestingly, we also found that alC activity increased prior to active but not inactive nose-pokes

287 across each phase of the experiment, indicating a potential role of alC in anticipating outcomes prior to

288 actions, and/or selectively promoting reinforced responses. Next, we used chemogenetics to show that

289 inhibition of alC decreased context-induced relapse of nicotine-seeking after both punishment-

290 imposed abstinence and after extinction. The chemogenetic experiments we conducted in both male

291 and female rats, and we observed a comparable effect of chemogenetic inhibition of alC in both sexes.

292 This study demonstrates the importance of nicotine-associated contexts in promoting relapse. We

293 show that the alC activity is critical for this effect, regardless of the mode of abstinence, further

294 highlighting the important role of alC in relapse of nicotine use.

\section{Methodological considerations}

296 Several issues must be considered in the interpretation of these findings. In this study, we used

297 intravenous nicotine during self-administration. While human nicotine use is primarily through cigarette

298 smoking, intravenous administration of nicotine is reinforcing in humans (39), demonstrating that a

299 comparable route of administration supports reinforcement in humans. In addition, smokeless tobacco

300 is also addictive and is responsible for many adverse health consequences (40). Recently it has been

301 shown that vapor administration of nicotine is effective in rodents $(41,42)$, and vapor exposure causes

302 both physical (43) and psychological effects $(41,44)$. The extent to which the route of self-

303 administration changes the neurobiological substrates of context-induced nicotine-seeking is

304 unknown, thus it will be of interest in future studies to determine this. However, because in this study

305 our focus is on the neurobiological substrates by which contexts associated with nicotine or 
bioRxiv preprint doi: https://doi.org/10.1101/2021.12.08 471717; this version posted December 9,2021 . The copyright holder for this preprint (which was not certified by peer review) is the author/funder, who has granted bioRxiv a license to display the preprint in perpetuity. It is made available under aCC-BY 4.0 International license.

punishment control nicotine-seeking, we argue that the route of administration is unlikely to change the contribution of the alC to these behaviors.

In the chemogenetics experiments, we used CLZ instead of Clozapine-N-Oxide (CNO) because CNO is converted to CLZ in-vivo (45), and made comparisons to the GFP group who also received CLZ. Various studies have estimated the conversion ratio of CNO to CLZ in rodents to be between $7.5 \%$ to $13 \%(46,47)$, which leads to an estimate dose used here of $5-10 \mathrm{mg} / \mathrm{Kg} \mathrm{CNO}$, a wellestablished CNO dose with minimal side-effects $(48,49)$. While we have not controlled for non-specific effects of hM4Di expression (i.e. no vehicle-hM4Di test sessions), we find it unlikely that hM4Di expression in the absence of ligand binding will change the function of alC given the low basal activity of this receptor $(35,50)$. Finally, because we used different promoters for viral-induced expression of calcium indicator (jGCamP7f: hSyn) and chemogenetic inhibition (hM4Di: mCaMKIla), the observations reported in the photometry experiment likely reflects activity of a population of neurons that were not manipulated in the chemogenetics experiments. It will be of interest in future studies to identify potential variation in the responses of aIC neuronal subpopulations to nicotine infusions and punishment.

\section{Role of aIC, BLA, and BLA inputs to aIC in context-induced relapse to nicotine-seeking.}

In pre-clinical studies, the role of alC in drug-seeking and relapse is well established (51-55). Bilateral electrical stimulation of the insula, at the level of mIC in this study, has been shown to decrease nicotine self-administration and both cue- and priming-induced reinstatement after extinction (56). Inactivation of both aIC and $\mathrm{mIC}$ can decrease nicotine self-administration, and both drug- and cue-induced reinstatement of extinguished nicotine-seeking $(54,57)$. Activity in alC is also necessary for relapse to alcohol seeking, particularly relapse in the punishment context after a period of extended home cage abstinence (52). Here, we demonstrated a role for alC in context-induced relapse to nicotine-seeking after both punishment- and extinction-imposed abstinence, further demonstrating the critical role of the alC in the control of drug seeking.

Our results also show increased activity in BLA during context-induced relapse after punishmentimposed abstinence. The role of BLA in cue- and stress- induced reinstatement of nicotine-seeking has been demonstrated previously (58-61), but to our knowledge this is the first time that BLA has been implicated in context-induced relapse of nicotine-seeking. We also show increased activation in 
bioRxiv preprint doi: https://doi.org/10.1101/2021.12.08.471717; this version posted December 9,2021 . The copyright holder for this preprint (which was not certified by peer review) is the author/funder, who has granted bioRxiv a license to display the preprint in perpetuity. It is made available under aCC-BY 4.0 International license.

335 the aBLA $\rightarrow$ alC pathway during context-induced relapse. Projections from BLA to alC are critical for 336 the maintenance of rewarding contextual stimuli (62). It has been proposed that the more posterior IC 337 regions contribute strongly to the function of the alC (63). However, we did not observe any increased 338 activity in $\mathrm{mIC} \rightarrow$ alC or pIC $\rightarrow$ alC neurons (either ipsi- or contra-lateral) in rats tested for context-

339 induced relapse. Given that in this experiment, the nicotine-associated context promotes nicotine340 seeking, we propose that the motivational significance of the nicotine-associated context is likely 341 mediated through increased activity in BLA $\rightarrow$ alC neurons and not $\mathrm{mIC}$ or plC neurons.

342 We also found increased Fos in contralateral alC projections during context-induced relapse.

343 Cortico-cortical pathways are primarily thought to result in feed-forward inhibition through targeting of 344 the PV interneurons in the contralateral hemisphere $(64,65)$. The contribution of contralateral cortico345 cortical projections to the functions of the frontal cortex is poorly understood, and the importance of 346 this pathway in the regulation of context-induced nicotine-seeking studied is likewise undetermined.

\section{Role of alC in the regulation of nicotine taking, punishment, and seeking}

Our results using fiber photometry revealed increased alC neural activity after nose-pokes in all

349 phases of the task. While this suggests that alC activity may be generally important in encoding 350 response-outcome contingencies, we observed important differences in the patterns of activity in the 351 different phases. In self-administration, alC activity was highest following nose-pokes that lead to 352 nicotine infusions. During punishment, the response to nicotine infusions changed such that there was 353 no longer a difference between nicotine reinforced nose-pokes and non-reinforced active nose-pokes.

354 In contrast alC activity in response to the punished nose-pokes was significantly higher than all other 355 outcomes. Such a change in the response of alC to (non-punished) nicotine infusion in punishment 356 may reflect a re-evaluation of nicotine reward encoding within aIC because the punishment overcomes 357 the motivation for nicotine and suppresses nicotine seeking. The observed reduction in nicotine 358 seeking in punishment is an adaptive response, thus we propose that during operant behavior alC 359 activity may be involved in the adaptation of behavior in response to both rewarding (i.e. nicotine) and 360 aversive outcomes (i.e. punishment). It will be of interest in future studies to determine whether 361 maladaptive responses to punishment, such as the punishment-resistance phenotype (66), are

362 associated with differences in the response to either reward or punishment in alC. Interestingly, 363 previous studies in alcohol trained rats have identified a critical role for alC in punished alcohol 364 seeking (67). 
bioRxiv preprint doi: https://doi.org/10.1101/2021.12.08.471717; this version posted December 9,2021 . The copyright holder for this preprint (which was not certified by peer review) is the author/funder, who has granted bioRxiv a license to display the preprint in perpetuity. It is made available under aCC-BY 4.0 International license.

The insular cortex is known to support a general function of integrating interoceptive information (68), which can play an important role in addictive behaviors. Interoceptive information and external signals from environmental cues converge at the anterior insula $(69,70)$. In human clinical studies, insula activity is related to both positive and negative emotional reactivity. For example nicotineassociated cue exposure increases alC activity in nicotine addicted individuals $(24,27,71,72)$, and aversive motivational states associated with short-term nicotine withdrawal are also linked to changes

371 in resting state functional connectivity between the insula and associated brain regions $(73,74)$.

372 Furthermore in non-addicted humans, insula activity is associated with punishment in a risky decision373 making task (75). Positive and negative valence signals are integrated in the insula to guide motivated behavior through increased activity in the divergent outputs of insula to various brain regions $(68,70$, 76-82). It will be of interest in future studies to determine whether the activity related to both positive (nicotine infusion) and negative (punished nicotine infusion) outcomes recorded at the population level in our study are selectively encoded through different output pathways of alC.

Finally, we also found that alC activity increased relative to baseline prior to an active nose-poke,

379 but not inactive nose-pokes. We are unsure about the significance of this, however this pattern of 380 activity is consistent throughout the experiment. Other studies have shown that activity in alC is 381 necessary for the performance of goal-directed behavior $(83,84)$, but it is not necessary for initial 382 acquisition (85). We propose that the activity prior to the response differentiating between active and 383 inactive nose-pokes may indicate that alC activity can contribute to the encoding of expectations in 384 operant behavior. Which may be consistent with a broader role of IC in the prediction of bodily states $385(70,86)$

386 Similarities and differences in the neural control of relapse after punishment vs extinction.

Distinct learning mechanisms are responsible for behavioral control after extinction or punishment.

388 Both are mediated by new context-dependent associations $(15,87)$. However, punishment learning 389 involves the acquisition of an association between the response and a novel outcome (shock), while 390 extinction involves the acquisition of an association between the response and no outcome. Here we 391 show that bilateral chemogenetic inhibition of alC decreases context-induced relapse of both punished 392 and extinguished nicotine-seeking. Previous studies investigating relapse of either alcohol or cocaine 393 seeking have identified differences in the mechanisms of relapse after punishment or extinction. For 394 example, while dopamine receptor activation in nucleus accumbens core is critical for context-induced 
relapse of punished alcohol seeking $(18,19)$, no increase in Fos was observed in nucleus accumbens core after context-induced relapse of extinguished alcohol seeking $(88,89)$. Inactivation of basolateral

397 amygdala potentiates cocaine seeking after punishment, but decreases cocaine seeking after extinction (21). Meanwhile, inactivation of central amygdala had no effect on cocaine seeking after

399 punishment, but decreased cocaine seeking after extinction (21). We propose that this finding demonstrates the importance of the alC in context-induced relapse, regardless of the method used to

401 impose abstinence. It has previously been demonstrated that inhibiting alC decreases relapse of methamphetamine seeking after choice-based voluntary abstinence (55). As such the role of alC in

403 relapse is likely broader than just for context-induced relapse of nicotine-seeking. It will be of interest

404 in future studies to determine whether this distinction holds true for other drugs of abuse, or indeed for 405 other types of voluntary abstinence such as choice for social reward (90).

\section{Concluding remarks.}

407 We sought to investigate the neural substrates of context-induced relapse to nicotine-seeking after 408 punishment-imposed abstinence. Our results show that activity in alC is necessary for context-induced 409 relapse of punished nicotine-seeking, and this is also the case for extinguished nicotine-seeking. We 410 also show that the BLA projections to alC are activated during context-induced relapse, and future 411 studies are needed to determine the extent to which this activity is necessary for this relapse. Our 412 findings further highlight the critical importance of the anterior insular cortex as a target for nicotine 413 addiction treatments. 


\section{Materials and Methods}

416

\section{Subjects}

We obtained 91 Wistar rats (29 male and 62 female), aged 10-12 weeks upon arrival, from Charles River Laboratories B.V. (Leiden, The Netherlands). In compliance with Dutch law and Institutional regulations, all animal procedures were approved by the Centrale Commissie Dierproeven (CCD) and conducted in accordance with the Experiments on Animal Act. Experiments were approved by the local animal welfare body Animal Experiments Committee of the Vrije Universiteit, Amsterdam, The Netherlands. Behavioral tests were conducted during the dark phase of the rat's diurnal cycle (12h/12h). Food and water were available ad libitum, and rats were single-housed the rats after surgery for the remainder of the experiment.

We did not make a specific power analysis to determine sample size prior to any experiments. The group size was chosen based on our past research (7) suggesting that it will be sufficient to observe significant effects of the role of context on nicotine seeking. Each experiment is comprised of data from at least one replication cohort, and cohorts were balanced by viral group, sex, prior to the start of the experiment. We allocated the rats randomly to one of the groups within each experiment, but we were not blinded to the specific group because we were required to administer virus. We did not exclude any rats for reasons of behavioral variation (i.e. no outliers have been removed), but rats that did not have correct placement of CTb injection, or expression of jGCaMP or DREADD, within anterior insula were removed from the experiment

\section{Apparatus}

All procedures were performed in standard Med Associates operant chambers with data collected through the MED-PC IV program (Med Associates, Georgia, VT, USA). Each chamber had one "active" and one "inactive" nose-poke hole on one wall and a grid floor connected to shock controllers. Contexts A and B were defined by houselight (on/off), cue-light color (white/red), and white noise (on/off).

The catheter for intravenous nicotine delivery was composed of a cannula connector pedestal (Plastics One, Minneapolis, MN, USA), attached to a $95 \mathrm{~mm}$ silicone catheter (BC-2S; 0,3 mm x 0,6 $\mathrm{mm}$; UNO B.V., Zevenaar, The Netherlands) and a $6 \mathrm{~mm}$ piece of polyethylene tubing $(0,75 \mathrm{~mm} \mathrm{x}$ 1,45mm; UNO B.V., Zevenaar, The Netherlands) clamping the silicone catheter to the connector 
pedestal. A small ball of silicone (RTV-1 Silicone Rubber / Elastosil $\AA$ ) is attached $38 \mathrm{~mm}$ from the end of the silicone catheter.

For fiber photometry, excitation and emission light was relayed to and from the animal via optical fibre patch cord (0.48 NA, $400 \mu \mathrm{m}$ flat tip; Doric Lenses). Blue excitation light (490 or 470nm LED [M490F2 or M470F2, Thorlabs]) was modulated at $211 \mathrm{~Hz}$ and passed through a 460-490nm filter (Doric Lenses), while isosbestic light (405nm LED [M405F1, Thorlabs]) was modulated at $531 \mathrm{~Hz}$ and passed through a filter cube (Doric Lenses). GCaMP7f fluorescence was passed through a 500550nm emission filter (Doric Lenses) and onto a photoreceiver (Newport 2151). Light intensity at the tip of the fiber was measured before every training session and kept at $21 \mathrm{uW}$. A real-time processor (RZ5P, Tucker Davis Technologies) controlled excitation lights, demodulated fluorescence signals and received timestamps of behavioural events. Data was saved at $1017.25 \mathrm{~Hz}$ and analyzed with custommade Matlab scripts.

\section{Drugs}

Nicotine (nicotine hydrogen tartrate salt, Sigma-Aldrich, St. Louis, MO, USA) was dissolved in normal saline, filtered, and pH-adjusted to 7.4. Clozapine was dissolved first in a small amount of

459 glacial acetic acid (volume used was $0.1 \%$ of the final CLZ volume) and progressively diluted in saline until a final concentration of $0.3 \mathrm{mg} / \mathrm{ml}(\mathrm{pH}$ was adjusted to $7.0-7.2)$.

\section{Viral vectors}

We purchased premade viral vectors from the University of Zurich viral vector core: AAV-5/2-

463 mCaMKIla-HA_hM4D(Gi)-IRES-mCitrine-WPRE-hGHp(A) (hM4Di), AAV-5/2-mCaMKIla-EGFP464 WPRE-hGHp(A) (GFP), AAV-9/2-hSyn1-chl-jGCaMP7f-WPRE-SV40p(A) (jGCaMP7f). The titer

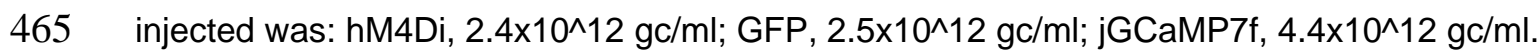

\section{Surgery}

Thirty minutes prior to surgery, we injected rats with the analgesic Rymadil ${ }^{(}(5 \mathrm{mg} / \mathrm{kg}$; Merial,

468 Velserbroek, The Netherlands) and the antibiotic Baytril( $(8.33 \mathrm{mg} / \mathrm{kg}$; Bayer, Mijdrecht). Surgery was 469 performed under isoflurane gas anesthesia ( $\mathrm{PCH}$; Haarlem). The silicone catheter was tunneled from 470 the scalp to the neck and was inserted into the jugular vein, where it was secured using sterile thread.

471 We sealed the silicone catheter using a taurolidine-citrate solution (TCS; Access Technologies,

472 Skokie, IL) and a polyethylene cap. After the catheter was implanted, we placed the rat in a 
bioRxiv preprint doi: https://doi.org/10.1101/2021.12.08 471717; this version posted December 9,2021 . The copyright holder for this preprint (which was not certified by peer review) is the author/funder, who has granted bioRxiv a license to display the preprint in perpetuity. It is made available under aCC-BY 4.0 International license.

stereotactic frame (David Kopf Instruments, Tujunga, CA) and injected Xylocaïne 2\% with adrenaline (10 mg/kg; Astra Zeneca, Zoetermeer, The Netherlands) into the incision site prior to the incision. A craniotomy above alC was performed, followed by CTb or AAV injections (see below for details). After filling the skull hole with bone wax, cannula tubing connected to a Plastics One Connector-Pedestal and optic fiber implant (when applicable) was secured to the skull using dental cement (IV Tetric EvoFlow $2 \mathrm{~g} \mathrm{A1}$, Henry Schein, Almere) and jewelers screws. Rymadil (5 mg/kg; s.c.) was administered for 2 days after the surgery. Rats were given one week of recovery following surgery. CTb injections: $40 \mathrm{nl}$ of 1\% CTb (List Biological Laboratories) was injected unilaterally (left or right) into alC (AP: +2.8, ML: +4.0, DV: -5.9 mm from Bregma) over 2 min using $1.0 \mu \mathrm{l} 32$ gauge "Neuros" syringe (Hamilton) attached to a UltraMicroPump (UMP3) with SYS-Micro4 Controller (World Precision Instruments). The needle was left in place for an additional 2 min after injections.

AAV injections for fiber photometry: $0.5 \mu \mathrm{l}$ of AAV solution was injected unilaterally (left or right) into alC (AP: $+2.8, \mathrm{ML}:+4.0$, DV: $-6.0 \mathrm{~mm}$ from Bregma) over $5 \mathrm{~min}$. The needle was left in place for an additional $5 \mathrm{~min}$. A 400 $\mu \mathrm{m}$ optic fiber (Doric Lenses) was then implanted above alC (AP: $+2.8, \mathrm{ML}$ : +4.0, DV: -5.6 mm from Bregma).

$\underline{A A V}$ injections for chemogenetics: $1.0 \mu \mathrm{l}$ of AAV solution was injected bilaterally into alC (AP: +2.8, ML: +4.0, DV: -5.9 mm from Bregma) over 5 min using $10 \mu \mathrm{l}$ Nanofil syringes (World Precision Instruments), with 33 gauge needles, attached to a UltraMicroPump (UMP3) with SYS-Micro4 Controller (World Precision Instruments). The needle was left in place for an additional 5 min.

\section{Behavioral procedure}

\section{Phase 1: Nicotine self-administration (SA: Context A):}

On the day prior to self-administration, before and after each self-administration session and during weekends, rat's catheters were flushed with approx. $0.1 \mathrm{ml}$ mixture of heparin $(0.25 \mathrm{mg} / \mathrm{ml}$; Serva, Heidelberg, Germany) and gentamicin sulfate $(0.08 \mathrm{mg} / \mathrm{ml}$; Serva, Heidelberg, Germany). Rats were trained to self-administer nicotine in 2-hour sessions, five days a week. Entry into the active nose-poke resulted in intravenous nicotine delivery infused over approximately 2 seconds (infusion time adjusted for weight) at $30 \mu \mathrm{g} / \mathrm{kg} /$ infusion. Nicotine infusion was paired with a 20 -second time-out period with the cue-light on. During time-out, responses were recorded but had no consequence. Inactive nose-pokes had no effect in either context. Rats were first trained on a fixed-ratio (FR) 1 schedule, which was then 
bioRxiv preprint doi: https:/doi.org/10.1101/2021.12 08.471717: this version posted December 9 2021. The copyright holder for this preprint (which was not certified by peer review) is the author/funder, who has granted bioRxiv a license to display the preprint in perpetuity. It is made available under aCC-BY 4.0 International license.

502 increased to FR-2, followed by FR-3. We tested catheter patency using intravenous anesthetic $0.05 \mathrm{cc}$ 503 pentothal (thiopenthal sodium, $50 \mathrm{mg} / \mathrm{ml}$ ).

$504 \quad$ Phase 2A: Punishment of nicotine self-administration (PUN, Context B)

505 Nicotine self-administration was maintained on the FR-3 schedule, and $50 \%$ of the reinforced

506 active nose-pokes (pseudo-randomly determined by the Med-PC program) resulted in footshock ( 0.30

$507 \mathrm{~mA}$ for $0.5 \mathrm{sec})$ and nicotine infusion.

508 Phase 2B: Extinction of nicotine-seeking (EXT, Context B)

509 Entry into the active nose-poke resulted in simultaneous activation of the cue light and delivery of

510 the same volume of saline through the jugular catheter (FR-3 schedule).

511 Phase 3: Relapse tests in Context A (SA) \& Context B (PUN or EXT)

512 Following abstinence (PUN or EXT), rats were tested in context $A$ and context $B$. The response

513 contingent CS was presented on an FR-3 schedule without punishment, saline or nicotine delivery. For

514 the CTb+Fos experiment (Exp. 1), rats were tested for one 60 minute session and perfused 90

515 minutes after the beginning of the test. For the chemogenetics experiments (Exp. 3 and 4) rats were

516 tested in both contexts A and B (counterbalanced order). 30 min prior to the relapse test sessions, we

517 injected both GFP and hM4Di expressing rats with clozapine at a dose of $0.3 \mathrm{mg} / \mathrm{kg}$ injection (i.p.).

\section{Immunohistochemistry}

519 We deeply anesthetized rats with isoflurane and Euthasol® injection (i.p.) and transcardially

520 perfused them with $\sim 100 \mathrm{ml}$ of normal saline followed by $\sim 400 \mathrm{ml}$ of $4 \%$ paraformaldehyde in $0.1 \mathrm{M}$

521 sodium phosphate $(\mathrm{pH} 7.4)$. The brains were removed and post-fixed for $2 \mathrm{~h}$, and then $30 \%$ sucrose in

$5220.1 \mathrm{M}$ PBS for $48 \mathrm{~h}$ at $4^{\circ} \mathrm{C}$. Brains were then frozen on dry ice, and coronal sections were cut $(40 \mu \mathrm{m})$

523 using a Leica Microsystems cryostat and stored in $0.1 \mathrm{M}$ PBS containing $1 \%$ sodium azide at $4^{\circ} \mathrm{C}$.

524 Immunohistochemical procedures are based on our previously published work $(17,19,89)$. We

525 selected a 1 -in- 4 series and first rinsed free-floating sections $(3 \times 10$ minutes $)$ before incubation in

526 PBS containing 0.5\% Triton-X and 10\% Normal Donkey Serum (NDS) and incubated for at least $48 \mathrm{~h}$

527 at $4^{\circ} \mathrm{C}$ in primary antibody. Sections were then repeatedly washed with PBS and incubated for $2-4 \mathrm{~h}$ in

528 PBS $+0.5 \%$ Triton- $X$ with $2 \%$ NDS and secondary antibody. After another series of washes in PBS, 
bioRxiv preprint doi: https://doi.org/10.1101/2021.12.08.471717; this version posted December 9,2021 . The copyright holder for this preprint (which was not certified by peer review) is the author/funder, who has granted bioRxiv a license to display the preprint in perpetuity. It is made available under aCC-BY 4.0 International license.

slices were stained with DAPI $(0.1 \mathrm{ug} / \mathrm{ml})$ for $10 \mathrm{~min}$ prior to mounting onto gelatin-coated glass slides, air-drying and cover-slipping with Mowiol and DABCO.

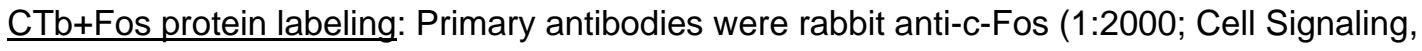
CST5348S) and goat anti-CTb (1:5000; List Biological Laboratories, 703). Secondary antibodies were donkey anti-rabbit Alexa Fluor 594 (1:500; Molecular Probes, A21207) and donkey anti-goat Alexa Fluor 488 (1:500: Molecular Probes, A11055).

Photometry experiment: Primary antibodies were mouse anti-NeuN primary antibody (1:1000; Chemicon, MAB377) and rabbit anti-GFP primary antibody (1:2000; Chemicon, AB3080). Secondary antibodies were donkey anti-mouse DyLight 649 (1:500; Jackson ImmunoResearch, 715-495-150) and donkey anti-rabbit Alexa Fluor 594 (1:500: Mol. Probes, A21207).

Chemogenetic inhibition experiments: Primary antibody was rabbit anti-GFP primary antibody (1:2000; Chemicon, AB 3080) and secondary antibody was donkey anti-rabbit Alexa Fluor 594 (1:2000; Molecular Probes, A21207). In rats in the GFP group, slices were only stained with DAPI.

\section{Image acquisition and neuronal quantification}

Slides were all imaged on a VectraPolaris slide scanner (VUmc imaging core) at 10x magnification. For the $\mathrm{CTb}+$ Fos experiment (Exp. 1), images from Bregma +4.0 to Bregma -3.3 were scanned and imported into QuPath for analysis (91). For photometry and chemogenetic experiments, images containing alC, from Bregma $+4.2 \mathrm{~mm}$ to $+2.5 \mathrm{~mm}$ were identified and the boundary of expression for each rat was plotted onto the respective Paxinos and Watson atlas (92). Rats in Experiment 1 that had a CTb injection not within alC were excluded from analysis. Rats in Experiments 4 and 5 that had either unilateral expression or misplaced expression were excluded from the analysis.

Fos, CTb, and CTb+Fos quantification: Regions of interest were manually labeled across sections using DAPI for identification of anatomical landmarks and boundaries. For the IC, we labeled 18 sections per hemisphere per rat spaced approximately 400 microns apart. For analysis, we separated IC into three regions anterior (alC), middle $(\mathrm{mlC})$, and posterior $(\mathrm{plC})$, and each value was the result of an average of each count from six adjacent sections: alC (approx. Bregma +3.72 to +1.44 ), $\mathrm{mIC}$ (approx. Bregma +1.08 to -0.72 ), pIC (approx. Bregma -1.08 to -2.92 ). For BLA, we labeled 6 sections spaced approximately 200 microns apart, and we separated it into anterior BLA (aBLA) and posterior BLA (pBLA), which is the average value of three adjacent sections: aBLA (approx. Bregma -1.92 to - 
2.40), pBLA (approx. Bregma -2.64 to -3.12). Some rats had missing sections due to mistakes during the process, and these sections were left blank for the statistical analyses.

To identify Fos- and CTb-positive cells, we used the 'Cell detection' feature in QuPath, with an identical threshold applied across all sections. CTb was not counted for the first six sections in the ipsilateral alC, where the CTb injection was located, because the cell detection feature could not reliably discriminate between $\mathrm{CTb}$ positive cell and the $\mathrm{CTb}$ injection. The total number of positive cells per region was divided by the area in mm2. To identify $\mathrm{CTb}+$ Fos cells, each region of interest was exported to ImageJ. The overlays representing the cells (CTb or Fos) were then filled, converted to a binary layer, and then multiplied using the ImageJ function 'Image calculator'. The nuclei that remained as a result of this function were counted as double-labeled $\mathrm{CTb}+\mathrm{Fos}$ neurons. $\mathrm{CTb}+\mathrm{Fos}$ double labelling is reported as a percentage of total CTb neurons for that given region of interest.

\section{Ex-vivo slice physiology}

Coronal slices were prepared for electrophysiological recordings. Rats were anesthetized ( $5 \%$ isoflurane, i.p. injection of $0.1 \mathrm{ml} / \mathrm{g}$ pentobarbital) and perfused with ice-cold N-Methyl-D-glucamin

572 (NMDG) solution containing (in mM): NMDG 93, KCl 2.5, NaH2PO4 1.2, NaHCO3 30, HEPES 20,

573 Glucose 25 , sodium ascorbate 5 , sodium pyruvate 3 , $\mathrm{MgSO} 472 \mathrm{H} 2 \mathrm{O} 10, \mathrm{CaCl}{ }^{\star} 2 \mathrm{H} 2 \mathrm{O} 0.5$, at $\mathrm{pH} 7.3$

574 adjusted with $10 \mathrm{M} \mathrm{HCl}$. The brains were removed and incubated in ice-cold NMDG solution. $300 \mu \mathrm{m}$

575 thick brain slices were cut in ice-cold NMDG solution and subsequently incubated for 15-30 min at 34 $576{ }^{\circ} \mathrm{C}$.

Before the start of experiments, slices were allowed to recover for at least 1 hour at room 578 temperature in carbogenated (95\% O2/5\% CO2) ACSF solution containing (in $\mathrm{mM}$ ): $\mathrm{NaCl} 125, \mathrm{KCl} 3$,

$579 \mathrm{NaH} 2 \mathrm{PO} 4$ 1.2, NaHCO3 25, Glucose 10, $\mathrm{CaCl} 2$ 2, MgSO4 1. For voltage- and current-clamp

580 experiments borosilicate glass patch-pipettes (3-5 M $\Omega$ ) were used with a K-gluconate-based internal

581 solution containing (in mM): K-gluconate 135, $\mathrm{NaCl} 4$, MgATP 2, Phosphocreatine 10, GTP (sodium 582 salt) 0.3 , EGTA 0.2, HEPES 10 at a pH of 7.4. Data was sampled using a Multiclamp 700B amplifier 583 (Axon Instruments) and pClamp software (Molecular Devices). All recordings were made between $58431.1^{\circ} \mathrm{C}$ and $33.6^{\circ} \mathrm{C}$.

\section{Experimental design}


bioRxiv preprint doi: https://doi.org/10.1101/2021.12.08.471717: this version posted December 9,2021 . The copyright holder for this preprint (which was not certified by peer review) is the author/funder, who has granted bioRxiv a license to display the preprint in perpetuity. It is made available under aCC-BY 4.0 International license.

Exp. 1: CTb + Fos after context-induced relapse of punished nicotine-seeking ( $\mathrm{n}=18$ female. Cohort

$1, n=11$; cohort $2, n=7)$. Fig. 1 A shows the experimental outline. We first trained rats to self-administer nicotine in one context (context $\mathrm{A}$ ) in $2 \mathrm{~h}$ sessions per day for 15 days ( 4 sessions FR-1, 6 sessions FR-2, 5 sessions FR-3). Next, the rats underwent punishment in the alternate context (context B) $2 \mathrm{~h}$ per day for 7 days. During these sessions, active nose-pokes (FR-3 schedule) resulted in the presentation of the cue-light $(20 \mathrm{sec})$, nicotine infusion, and $50 \%$ probability of $0.3 \mathrm{~mA}$ footshock

592 punishment. Finally, the rats were tested under extinction conditions. One group of rats $(n=7)$ was tested in the nicotine self-administration context (context $A)$, one group $(n=8)$ was tested in the

594 punishment context (context B), and a third group $(n=3)$ was taken from the home-cage without test.

595 We perfused rats 90 min after the start of the 60 minute test.

Exp.2: Calcium imaging of alC activity during nicotine self-administration, punishment, and contextinduced relapse ( $n=7$ female. Cohort $1, n=3$; cohort $2, n=4)$ : Fig. $2 A$ shows the experimental outline.

598 Photometry sessions were 1 hour in duration. Tubing delivering nicotine was run down along the patch-cord and to the connection in the implant. If the tubing became tangled, the rat was manually rotated in the opposite direction or, if it was within 10 minutes of the end of the session, the session

601 was ended early. Rats were trained to self-administer nicotine in context A (7 days FR-1, 3 days FR-2,

6028 days FR-3). We next punished nicotine self-administration in context B for 6 days (first cohort; $n=3$ )

603 or 10 days (second cohort; $n=3$ ), one rat only received 4 days of punishment. In this phase $50 \%$ of

604 nicotine infusions were paired with electric shock. After punishment-imposed abstinence, nicotine-

605 seeking was tested in context A in $2 \times 1$ hour sessions over 2 consecutive days.

606 Exp. 3: Chemogenetic validation ( $n=3$ female, $n=3$ male): Six rats were unilaterally injected with $6071.0 \mu \mathrm{l}$ of AAV encoding the inhibitory DREADD hM4Di into alC (AP: +2.8, ML: +4.0, DV: $-5.9 \mathrm{~mm}$ from

608 Bregma). Rats were sacrificed 4-5 weeks later for ex-vivo physiology.

609 Exp. 4: Effect of chemogenetic inhibition of alC on context-induced relapse of punished nicotine-

610 seeking $(n=28(13 M / 15 F)$. Cohort $1, n=17(8 M / 9 F)$; cohort $2, n=11(5 M / 6 F))$. Fig. 4A shows the

611 experimental outline. We first trained rats to self-administer nicotine in context A (4 days FR-1, 4 days

612 FR-2, 5 days FR-3). We next punished nicotine self-administration in context B for 6 days. We then

613 tested rats in both contexts (A and B), over 2 consecutive days, and the order was counterbalanced.

61430 min prior to the test session, we injected both GFP and hM4Di expressing rats with clozapine (0.3 
bioRxiv preprint doi: https://doi org/10.1101/2021.12.08.471717; this version posted December 9,2021 . The copyright holder for this preprint (which was not certified by peer review) is the author/funder, who has granted bioRxiv a license to display the preprint in perpetuity. It is made available under aCC-BY 4.0 International license.

$615 \mathrm{mg} / \mathrm{kg}$ injection (i.p.). We excluded 3 female rats from the hM4Di group because of a lack of bilateral 616 hM4Di expression in alC.

617 Exp. 5: Effect of chemogenetic inhibition of alC on context-induced relapse of extinguished nicotine-seeking $(n=31(13 M / 18 F)$. Cohort $1, n=22(11 M / 11 F)$; cohort 2, $n=9(2 M / 7 F))$. Fig. 5A shows

619 the experimental outline. We first trained rats to self-administer nicotine in context A on FR-1 (4 days), then FR-2 (4 days), then FR-3 (5 days). Next, we extinguished nicotine-seeking by saline infusion in context B (EXT) for 8 days. We then tested rats in both contexts ( $A$ and $B$ ), over 2 consecutive days, and the order was counterbalanced. 30 min prior to the test session, we injected both GFP and hM4Di expressing rats with clozapine $(0.3 \mathrm{mg} / \mathrm{kg}$ injection (i.p.).

\section{Statistics}

All behavioral data was analyzed using IBM SPSS V21. Phases were analyzed separately.

626 Dependent variables were the total number of active and inactive nose-pokes across phases, and 627 nicotine infusions for nicotine self-administration and punishment phases. For the CTb+Fos test (Exp.

628 1) we used a repeated measures analysis of variance (ANOVA) with Nose-Poke (Active, Inactive) as a 629 within-subjects factor and Test Context (context A, context B) as the between-subjects factor. To 630 analyze $\mathrm{CTb}+$ Fos expression, we used one-way ANOVA to test for an effect of Test Context (Home631 cage, Punishment, Nicotine) on Fos, CTb, and \% CTb+Fos/CTb. Follow-up tests (Tukey) were 632 conducted on regions that had a significant main effect of Test Context. For the chemogenetic 633 experiments we used repeated measures ANOVA with Test Context (context A, context B) and Nose634 Poke (Active, Inactive) as within-subjects factors, and Virus (GFP, hM4Di) and Sex (Female, Male) as 635 between-subjects factors.

636 Photometry: Recorded signals were first downsampled by a factor of 64 , giving a final sampling 637 rate of $15.89 \mathrm{~Hz}$. The $405 \mathrm{~nm}$ isosbestic signal was fit to the $490 \mathrm{~nm}$ calcium-dependent signal using a 638 first order polynomial regression. A normalized, motion-artefact-corrected $\Delta F / F$ was then calculated as 639 follows: $\Delta F / F=(490 \mathrm{~nm}$ signal - fitted $405 \mathrm{~nm}$ signal $) /$ fitted $405 \mathrm{~nm}$ signal. The resulting $\Delta F / F$ was then 640 detrended via a 90s moving average, and low-pass filtered at $3 \mathrm{~Hz} . \Delta \mathrm{F} / \mathrm{F}$ from $5 \mathrm{~s}$ before nosepoke 641 (baseline) to 10s after nosepoke were collated. These traces were then baseline-corrected and 642 converted into $z$-scores by subtracting the mean baseline activity during first 4 seconds of the baseline and dividing by the standard deviation of those 4 seconds. To avoid duplicate traces due to 
644 overlapping epochs, we excluded from the analyses any nosepokes that occurred within 20s after a

645 rewarded nosepoke (time-out), and un-rewarded active/inactive nosepokes that occurred 5s after

646 another active/inactive nosepoke.

647 Nosepoke traces were grouped by response type: active rewarded, active punished, active non-

648 rewarded, and inactive. Two analysis approaches were used, bootstrapping and permutation tests, the

649 rationale for each is described in detail in (38).

650 Bootstrapping was used to determine whether calcium activity per response type was significantly

651 different from baseline $(\Delta \mathrm{F} / \mathrm{F}=0)$. A distribution of bootstrapped means were obtained by randomly

652 sampling from traces with replacement ( $n$ traces for that response type; 5000 iterations). A 95\%

653 confidence interval was obtained from the $2.5^{\text {th }}$ and $97.5^{\text {th }}$ percentiles of the bootstrap distribution,

654 which was then expanded by a factor of $\operatorname{sqrt}(n /(n-1))$ to account for narrowness bias (38).

655 Permutation tests were used to assess significant differences in calcium activity between response

656 types. Observed differences between response-types were compared against a distribution of 1000

657 random permutations (difference between randomly regrouped traces) to obtain a $p$-value per time

658 point. Alpha of 0.05 was Bonferroni-corrected based on the number of comparison conditions,

659 resulting in alpha of 0.01 for comparisons between self-administration and test sessions ( 3 conditions)

660 and alpha of 0.008 for punishment sessions ( 4 conditions). For both bootstrap and permutation tests,

661 only periods that were continuously significant for at least 0.25 s were identified as significant (38).

662 


\section{Funding and Disclosure}

664 The work was supported by a Fulbright Fellowship to RH, and Austrian Science Fund (FWF) grant 665 SPIN supportW1206-12 to HG and GZ (graduate program Signal Processing In Neurons,

666 www.neurospin.at). The authors declare no conflict of interest.

\section{Acknowledgments}

668 The authors gratefully acknowledge the Histology Imaging Unit for their support \& assistance in 669 whole-slide imaging. The authors would like to thank Francesco Ferraguti for insightful comments in 670 the preparation of this manuscript.

\section{$671 \quad$ Author contributions}

672 Conducted experiments: HG, IAL, RH, DS, YvM, TH, NJM. Analyzed data: HG, IA, RH, PJRDB,

673 TH, NJM. First draft of manuscript: HG, IAL, NJM. Edited subsequent drafts and finalized manuscript: 674 HG, IAL, NJM, PJRDB, GZ, HM, TdV.

675 
bioRxiv preprint doi: https://doi.org/10.1101/2021.12.08.471717; this version posted December $9,2021$. The copyright holder for this preprint (which was not certified by peer review) is the author/funder, who has granted bioRxiv a license to display the preprint in perpetuity. It is made available under aCC-BY 4.0 International license.

\section{References}

1. O'Brien CP, Childress AR, McLellan AT, Ehrman R. Classical conditioning in drug-dependent humans. Ann N Y Acad Sci. 1992;654:400-15.

2. Waters AJ, Shiffman S, Sayette MA, Paty JA, Gwaltney CJ, Balabanis MH. Cue-provoked craving and nicotine replacement therapy in smoking cessation. J Consult Clin Psychol. 2004;72(6):113643.

682

3. Franklin TR, Wang Z, Wang J, Sciortino N, Harper D, Li Y, et al. Limbic activation to cigarette smoking cues independent of nicotine withdrawal: a perfusion fMRI study.

Neuropsychopharmacology. 2007;32(11):2301-9.

4. Bouton ME, Bolles RC. Contextual Control of the Extinction of Conditioned Fear. Learning and Motivation. 1979;10(4):445-66.

5. Ferguson SG, Shiffman S. The relevance and treatment of cue-induced cravings in tobacco dependence. J Subst Abuse Treat. 2009;36(3):235-43.

6. Crombag HS, Shaham Y. Renewal of drug seeking by contextual cues after prolonged extinction in rats. Behav Neurosci. 2002;116(1):169-73.

7. Diergaarde L, de Vries W, Raaso H, Schoffelmeer AN, De Vries TJ. Contextual renewal of nicotine seeking in rats and its suppression by the cannabinoid-1 receptor antagonist Rimonabant (SR141716A). Neuropharmacology. 2008;55(5):712-6.

8. Epstein $\mathrm{DH}$, Preston $\mathrm{KL}$. The reinstatement model and relapse prevention: a clinical perspective. Psychopharmacology (Berl). 2003;168(1-2):31-41.

9. Epstein DH, Preston KL, Stewart J, Shaham Y. Toward a model of drug relapse: an assessment of the validity of the reinstatement procedure. Psychopharmacology (Berl). 2006;189(1):1-16.

10. Marchant NJ, Khuc TN, Pickens CL, Bonci A, Shaham Y. Context-induced relapse to alcohol seeking after punishment in a rat model. Biol Psychiatry. 2013;73(3):256-62.

11. Panlilio LV, Thorndike EB, Schindler CW. Reinstatement of punishment-suppressed opioid selfadministration in rats: an alternative model of relapse to drug abuse. Psychopharmacology (Berl). 2003;168(1-2):229-35.

12. Pelloux $Y$, Everitt BJ, Dickinson A. Compulsive drug seeking by rats under punishment: effects of drug taking history. Psychopharmacology (Berl). 2007;194(1):127-37.

13. Vanderschuren LJ, Everitt BJ. Drug seeking becomes compulsive after prolonged cocaine selfadministration. Science. 2004;305(5686):1017-9.

14. Wolffgramm J, Heyne A. From controlled drug intake to loss of control: the irreversible development of drug addiction in the rat. Behav Brain Res. 1995;70(1):77-94.

15. Bouton ME, Schepers ST. Renewal after the punishment of free operant behavior. J Exp Psychol Anim Learn Cogn. 2015;41(1):81-90.

16. Farrell MR, Ruiz CM, Castillo E, Faget L, Khanbijian C, Liu S, et al. Ventral pallidum is essential for cocaine relapse after voluntary abstinence in rats. Neuropsychopharmacology. 2019;44(13):217485.

17. Marchant NJ, Campbell EJ, Whitaker LR, Harvey BK, Kaganovsky K, Adhikary S, et al. Role of Ventral Subiculum in Context-Induced Relapse to Alcohol Seeking after Punishment-Imposed Abstinence. J Neurosci. 2016;36(11):3281-94.

18. Marchant NJ, Kaganovsky K. A critical role of nucleus accumbens dopamine D1-family receptors in renewal of alcohol seeking after punishment-imposed abstinence. Behav Neurosci. 2015;129(3):281-91.

19. Marchant NJ, Rabei R, Kaganovsky K, Caprioli D, Bossert JM, Bonci A, et al. A critical role of lateral hypothalamus in context-induced relapse to alcohol seeking after punishment-imposed abstinence. J Neurosci. 2014;34(22):7447-57.

20. Pelloux Y, Hoots JK, Cifani C, Adhikary S, Martin J, Minier-Toribio A, et al. Context-induced relapse to cocaine seeking after punishment-imposed abstinence is associated with activation of cortical and subcortical brain regions. Addict Biol. 2018;23(2):699-712. 
bioRxiv preprint doi: https://doi.org/10.1101/2021.12.08.471717; this version posted December 9,2021 . The copyright holder for this preprint (which was not certified by peer review) is the author/funder, who has granted bioRxiv a license to display the preprint in perpetuity. It is made available under aCC-BY 4.0 International license.

21. Pelloux Y, Minier-Toribio A, Hoots JK, Bossert JM, Shaham Y. Opposite Effects of Basolateral Amygdala Inactivation on Context-Induced Relapse to Cocaine Seeking after Extinction versus Punishment. J Neurosci. 2018;38(1):51-9.

22. Naqvi NH, Rudrauf D, Damasio H, Bechara A. Damage to the insula disrupts addiction to cigarette smoking. Science. 2007;315(5811):531-4.

23. Brody AL, Mandelkern MA, London ED, Childress AR, Lee GS, Bota RG, et al. Brain metabolic changes during cigarette craving. Arch Gen Psychiatry. 2002;59(12):1162-72.

24. Kang OS, Chang DS, Jahng GH, Kim SY, Kim H, Kim JW, et al. Individual differences in smokingrelated cue reactivity in smokers: an eye-tracking and fMRI study. Prog Neuropsychopharmacol Biol Psychiatry. 2012;38(2):285-93.

25. Wang C, Huang P, Shen Z, Qian W, Li K, Luo X, et al. Gray matter volumes of insular subregions are not correlated with smoking cessation outcomes but negatively correlated with nicotine dependence severity in chronic smokers. Neurosci Lett. 2019;696:7-12.

26. Yalachkov $Y$, Kaiser J, Naumer MJ. Functional neuroimaging studies in addiction: multisensory drug stimuli and neural cue reactivity. Neurosci Biobehav Rev. 2012;36(2):825-35.

27. Gilman JM, Radoman M, Schuster RM, Pachas G, Azzouz N, Fava M, et al. Anterior insula activation during inhibition to smoking cues is associated with ability to maintain tobacco abstinence. Addict Behav Rep. 2018;7:40-6.

28. Ding $X$, Lee SW. Changes of functional and effective connectivity in smoking replenishment on deprived heavy smokers: a resting-state FMRI study. PLoS One. 2013;8(3):e59331.

29. Lerman C, Gu H, Loughead J, Ruparel K, Yang Y, Stein EA. Large-scale brain network coupling predicts acute nicotine abstinence effects on craving and cognitive function. JAMA Psychiatry. 2014;71(5):523-30.

30. Cruz FC, Koya E, Guez-Barber DH, Bossert JM, Lupica CR, Shaham Y, et al. New technologies for examining the role of neuronal ensembles in drug addiction and fear. Nat Rev Neurosci. 2013;14(11):743-54.

31. Herdegen T, Leah JD. Inducible and constitutive transcription factors in the mammalian nervous system: control of gene expression by Jun, Fos and Krox, and CREB/ATF proteins. Brain Research Reviews. 1998;28(3):370-490.

32. Morgan JI, Curran T. Stimulus-transcription coupling in the nervous system: involvement of the inducible proto-oncogenes fos and jun. Annu Rev Neurosci. 1991;14(1):421-51.

33. Cui G, Jun SB, Jin X, Pham MD, Vogel SS, Lovinger DM, et al. Concurrent activation of striatal direct and indirect pathways during action initiation. Nature. 2013;494(7436):238-42.

34. Gunaydin LA, Grosenick L, Finkelstein JC, Kauvar IV, Fenno LE, Adhikari A, et al. Natural neural projection dynamics underlying social behavior. Cell. 2014;157(7):1535-51.

35. Armbruster BN, Li X, Pausch MH, Herlitze S, Roth BL. Evolving the lock to fit the key to create a family of $G$ protein-coupled receptors potently activated by an inert ligand. Proc Natl Acad Sci U S A. $2007 ; 104(12): 5163-8$.

36. Marchant NJ, Campbell EJ, Pelloux Y, Bossert JM, Shaham Y. Context-induced relapse after extinction versus punishment: similarities and differences. Psychopharmacology (Berl). 2019;236(1):439-48.

37. Dana H, Sun Y, Mohar B, Hulse BK, Kerlin AM, Hasseman JP, et al. High-performance calcium sensors for imaging activity in neuronal populations and microcompartments. Nat Methods. 2019;16(7):649-57.

38. Jean-Richard-Dit-Bressel P, Clifford CWG, McNally GP. Analyzing Event-Related Transients: Confidence Intervals, Permutation Tests, and Consecutive Thresholds. Front Mol Neurosci. 2020;13:14.

39. MacLean RR, DeVito EE, Eid T, Parida S, Gueorguieva R, Sofuoglu M. Threshold dose for intravenous nicotine self-administration in young adult non-dependent smokers. Psychopharmacology (Berl). 2021;238(8):2083-90. 
bioRxiv preprint doi: https://doi.org/10.1101/2021.12.08.471717; this version posted December 9,2021 . The copyright holder for this preprint (which was not certified by peer review) is the author/funder, who has granted bioRxiv a license to display the preprint in perpetuity. It is made available under aCC-BY 4.0 International license.

40. Nethan ST, Sinha DN, Chandan K, Mehrotra R. Smokeless tobacco cessation interventions: A systematic review. Indian J Med Res. 2018;148(4):396-410.

41. Lallai V, Chen YC, Roybal MM, Kotha ER, Fowler JP, Staben A, et al. Nicotine e-cigarette vapor inhalation and self-administration in a rodent model: Sex- and nicotine delivery-specific effects on metabolism and behavior. Addict Biol. 2021:e13024.

42. Smith LC, Kallupi M, Tieu L, Shankar K, Jaquish A, Barr J, et al. Validation of a nicotine vapor selfadministration model in rats with relevance to electronic cigarette use. Neuropsychopharmacology. 2020;45(11):1909-19.

43. Montanari C, Kelley LK, Kerr TM, Cole M, Gilpin NW. Nicotine e-cigarette vapor inhalation effects on nicotine \& cotinine plasma levels and somatic withdrawal signs in adult male Wistar rats. Psychopharmacology (Berl). 2020;237(3):613-25.

44. Flores RJ, Alshbool FZ, Giner P, O'Dell LE, Mendez IA. Exposure to nicotine vapor produced by an electronic nicotine delivery system causes short-term increases in impulsive choice in adult male rats. Nicotine Tob Res. 2021.

45. Gomez JL, Bonaventura J, Lesniak W, Mathews WB, Sysa-Shah P, Rodriguez LA, et al. Chemogenetics revealed: DREADD occupancy and activation via converted clozapine. Science. 2017;357(6350):503-7.

46. MacLaren DA, Browne RW, Shaw JK, Krishnan Radhakrishnan S, Khare P, Espana RA, et al. Clozapine N-Oxide Administration Produces Behavioral Effects in Long-Evans Rats: Implications for Designing DREADD Experiments. eNeuro. 2016;3(5).

47. Manvich DF, Webster KA, Foster SL, Farrell MS, Ritchie JC, Porter JH, et al. The DREADD agonist clozapine $\mathrm{N}$-oxide (CNO) is reverse-metabolized to clozapine and produces clozapine-like interoceptive stimulus effects in rats and mice. Sci Rep. 2018;8(1):3840.

48. Mahler SV, Aston-Jones G. CNO Evil? Considerations for the Use of DREADDs in Behavioral Neuroscience. Neuropsychopharmacology. 2018;43(5):934-6.

49. Smith KS, Bucci DJ, Luikart BW, Mahler SV. DREADDS: Use and application in behavioral neuroscience. Behav Neurosci. 2016;130(2):137-55.

50. Urban DJ, Roth BL. DREADDs (designer receptors exclusively activated by designer drugs): chemogenetic tools with therapeutic utility. Annu Rev Pharmacol Toxicol. 2015;55(1):399-417.

51. Arguello AA, Wang R, Lyons CM, Higginbotham JA, Hodges MA, Fuchs RA. Role of the agranular insular cortex in contextual control over cocaine-seeking behavior in rats. Psychopharmacology (Berl). 2017;234(16):2431-41.

52. Campbell EJ, Flanagan JPM, Walker LC, Hill M, Marchant NJ, Lawrence AJ. Anterior Insular Cortex is Critical for the Propensity to Relapse Following Punishment-Imposed Abstinence of Alcohol Seeking. J Neurosci. 2019;39(6):1077-87.

53. Cosme CV, Gutman AL, LaLumiere RT. The Dorsal Agranular Insular Cortex Regulates the Cued Reinstatement of Cocaine-Seeking, but not Food-Seeking, Behavior in Rats. Neuropsychopharmacology. 2015;40(10):2425-33.

54. Pushparaj A, Kim AS, Musiol M, Trigo JM, Le Foll B. Involvement of the rostral agranular insular cortex in nicotine self-administration in rats. Behav Brain Res. 2015;290:77-83.

55. Venniro M, Caprioli D, Zhang M, Whitaker LR, Zhang S, Warren BL, et al. The Anterior Insular Cortex-->Central Amygdala Glutamatergic Pathway Is Critical to Relapse after Contingency Management. Neuron. 2017;96(2):414-27 e8.

56. Pushparaj A, Hamani C, Yu W, Shin DS, Kang B, Nobrega JN, et al. Electrical stimulation of the insular region attenuates nicotine-taking and nicotine-seeking behaviors. Neuropsychopharmacology. 2013;38(4):690-8.

57. Forget B, Pushparaj A, Le Foll B. Granular insular cortex inactivation as a novel therapeutic strategy for nicotine addiction. Biol Psychiatry. 2010;68(3):265-71.

58. Khaled MA, Pushparaj A, Di Ciano P, Diaz J, Le Foll B. Dopamine D3 receptors in the basolateral amygdala and the lateral habenula modulate cue-induced reinstatement of nicotine seeking. Neuropsychopharmacology. 2014;39(13):3049-58. 
bioRxiv preprint doi: https://doi.org/10.1101/2021.12.08.471717; this version posted December 9,2021 . The copyright holder for this preprint (which was not certified by peer review) is the author/funder, who has granted bioRxiv a license to display the preprint in perpetuity. It is made available under aCC-BY 4.0 International license.

59. Sharp BM. Basolateral amygdala, nicotinic cholinergic receptors, and nicotine: Pharmacological effects and addiction in animal models and humans. Eur J Neurosci. 2019;50(3):2247-54.

60. Xue YX, Chen YY, Zhang LB, Zhang LQ, Huang GD, Sun SC, et al. Selective Inhibition of Amygdala Neuronal Ensembles Encoding Nicotine-Associated Memories Inhibits Nicotine Preference and Relapse. Biol Psychiatry. 2017;82(11):781-93.

61. Yu G, Sharp BM. Basolateral amygdala and ventral hippocampus in stress-induced amplification of nicotine self-administration during reacquisition in rat. Psychopharmacology (Berl). 2015;232(15):2741-9.

62. Gil-Lievana E, Balderas I, Moreno-Castilla P, Luis-Islas J, McDevitt RA, Tecuapetla F, et al. Glutamatergic basolateral amygdala to anterior insular cortex circuitry maintains rewarding contextual memory. Commun Biol. 2020;3(1):139.

63. Mesulam MM, Mufson EJ. Insula of the old world monkey. III: Efferent cortical output and comments on function. J Comp Neurol. 1982;212(1):38-52.

64. Anastasiades PG, Marlin JJ, Carter AG. Cell-Type Specificity of Callosally Evoked Excitation and Feedforward Inhibition in the Prefrontal Cortex. Cell Rep. 2018;22(3):679-92.

65. Carson RG. Inter-hemispheric inhibition sculpts the output of neural circuits by co-opting the two cerebral hemispheres. J Physiol. 2020;598(21):4781-802.

66. Marchant NJ, Campbell EJ, Kaganovsky K. Punishment of alcohol-reinforced responding in alcohol preferring $P$ rats reveals a bimodal population: Implications for models of compulsive drug seeking. Prog Neuropsychopharmacol Biol Psychiatry. 2018;87(Pt A):68-77.

67. Seif T, Chang SJ, Simms JA, Gibb SL, Dadgar J, Chen BT, et al. Cortical activation of accumbens hyperpolarization-active NMDARs mediates aversion-resistant alcohol intake. Nat Neurosci. 2013;16(8):1094-100.

68. Paulus MP, Stewart JL. Interoception and drug addiction. Neuropharmacology. 2014;76 Pt B:34250.

69. Craig AD. Interoception: the sense of the physiological condition of the body. Curr Opin Neurobiol. 2003;13(4):500-5.

70. Livneh Y, Sugden AU, Madara JC, Essner RA, Flores VI, Sugden LA, et al. Estimation of Current and Future Physiological States in Insular Cortex. Neuron. 2020;105(6):1094-111 e10.

71. Janes AC, Pizzagalli DA, Richardt S, de BFB, Chuzi S, Pachas G, et al. Brain reactivity to smoking cues prior to smoking cessation predicts ability to maintain tobacco abstinence. Biol Psychiatry. 2010;67(8):722-9.

72. Janes AC, Gilman JM, Radoman M, Pachas G, Fava M, Evins AE. Revisiting the role of the insula and smoking cue-reactivity in relapse: A replication and extension of neuroimaging findings. Drug Alcohol Depend. 2017;179:8-12.

73. Fedota JR, Ding X, Matous AL, Salmeron BJ, McKenna MR, Gu H, et al. Nicotine Abstinence Influences the Calculation of Salience in Discrete Insular Circuits. Biol Psychiatry Cogn Neurosci Neuroimaging. 2018;3(2):150-9.

74. Ghahremani DG, Pochon JB, Perez Diaz M, Tyndale RF, Dean AC, London ED. Functional connectivity of the anterior insula during withdrawal from cigarette smoking. Neuropsychopharmacology. 2021;46(12):2083-9.

75. Von Siebenthal Z, Boucher O, Lazzouni L, Taylor V, Martinu K, Roy M, et al. Expected value and sensitivity to punishment modulate insular cortex activity during risky decision making. Sci Rep. 2020;10(1):11920.

76. Gehrlach DA, Dolensek N, Klein AS, Roy Chowdhury R, Matthys A, Junghanel M, et al. Aversive state processing in the posterior insular cortex. Nat Neurosci. 2019;22(9):1424-37.

77. Gehrlach DA, Weiand C, Gaitanos TN, Cho E, Klein AS, Hennrich AA, et al. A whole-brain connectivity map of mouse insular cortex. Elife. 2020;9.

78. Shi CJ, Cassell MD. Cortical, thalamic, and amygdaloid connections of the anterior and posterior insular cortices. J Comp Neurol. 1998;399(4):440-68. 
79. Wang L, Gillis-Smith S, Peng Y, Zhang J, Chen X, Salzman CD, et al. The coding of valence and identity in the mammalian taste system. Nature. 2018;558(7708):127-31.

80. Reynolds SM, Zahm DS. Specificity in the projections of prefrontal and insular cortex to ventral striatopallidum and the extended amygdala. J Neurosci. 2005;25(50):11757-67.

81. Kim U, Lee T. Topography of descending projections from anterior insular and medial prefrontal regions to the lateral habenula of the epithalamus in the rat. Eur J Neurosci. 2012;35(8):1253-69.

82. Nicolas C, Ju A, Wu Y, Eldirdiri H, Delcasso S, Jacky D, et al. Linking emotional valence and anxiety in a mouse insula-amygdala circuit. Research Square; 2021.

83. Parkes SL, Balleine BW. Incentive memory: evidence the basolateral amygdala encodes and the insular cortex retrieves outcome values to guide choice between goal-directed actions. J Neurosci. 2013;33(20):8753-63.

84. Parkes SL, Bradfield LA, Balleine BW. Interaction of insular cortex and ventral striatum mediates the effect of incentive memory on choice between goal-directed actions. J Neurosci. 2015;35(16):6464-71.

85. Parkes SL, Ferreira G, Coutureau E. Acquisition of specific response-outcome associations requires NMDA receptor activation in the basolateral amygdala but not in the insular cortex. Neurobiol Learn Mem. 2016;128:40-5.

894 86. Livneh Y, Andermann ML. Cellular activity in insular cortex across seconds to hours: Sensations and predictions of bodily states. Neuron. 2021.

87. Bouton ME. Context, ambiguity, and unlearning: sources of relapse after behavioral extinction. Biol Psychiatry. 2002;52(10):976-86.

88. Hamlin AS, Newby J, McNally GP. The neural correlates and role of D1 dopamine receptors in renewal of extinguished alcohol-seeking. Neuroscience. 2007;146(2):525-36.

89. Marchant NJ, Hamlin AS, McNally GP. Lateral hypothalamus is required for context-induced reinstatement of extinguished reward seeking. J Neurosci. 2009;29(5):1331-42.

90. Venniro M, Zhang M, Caprioli D, Hoots JK, Golden SA, Heins C, et al. Volitional social interaction prevents drug addiction in rat models. Nat Neurosci. 2018;21(11):1520-9.

904

905

91. Bankhead P, Loughrey MB, Fernandez JA, Dombrowski Y, McArt DG, Dunne PD, et al. QuPath: Open source software for digital pathology image analysis. Sci Rep. 2017;7(1):16878.

906

907

92. Paxinos G, Watson C. The rat brain in stereotaxic coordinates. Sixth edition. 3 ed. San Diego, CA: Academic Press; 2008. 


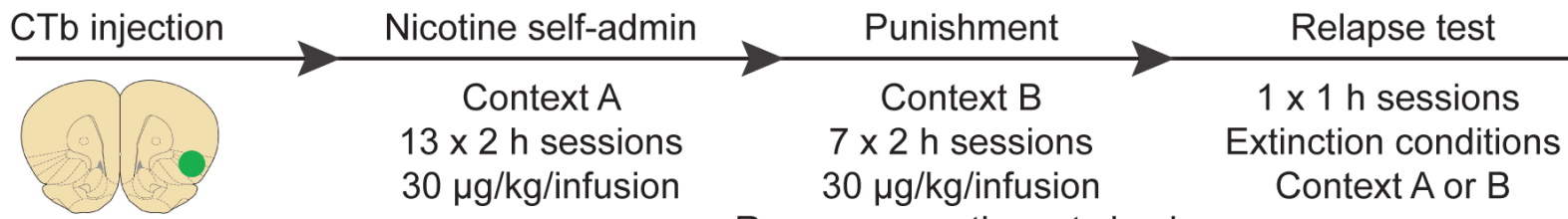

Response contingent shock

B

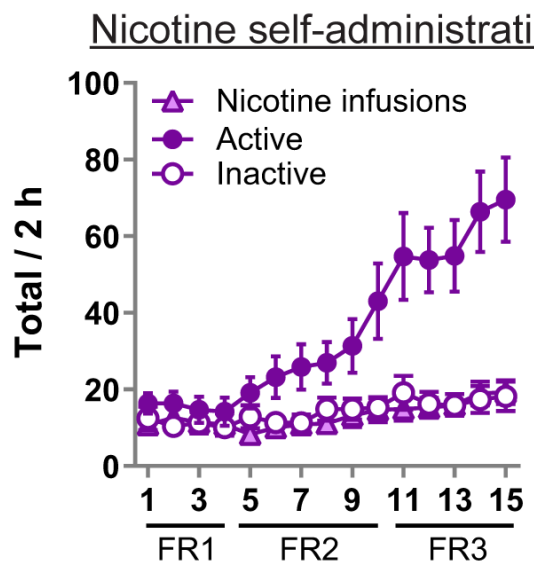

E
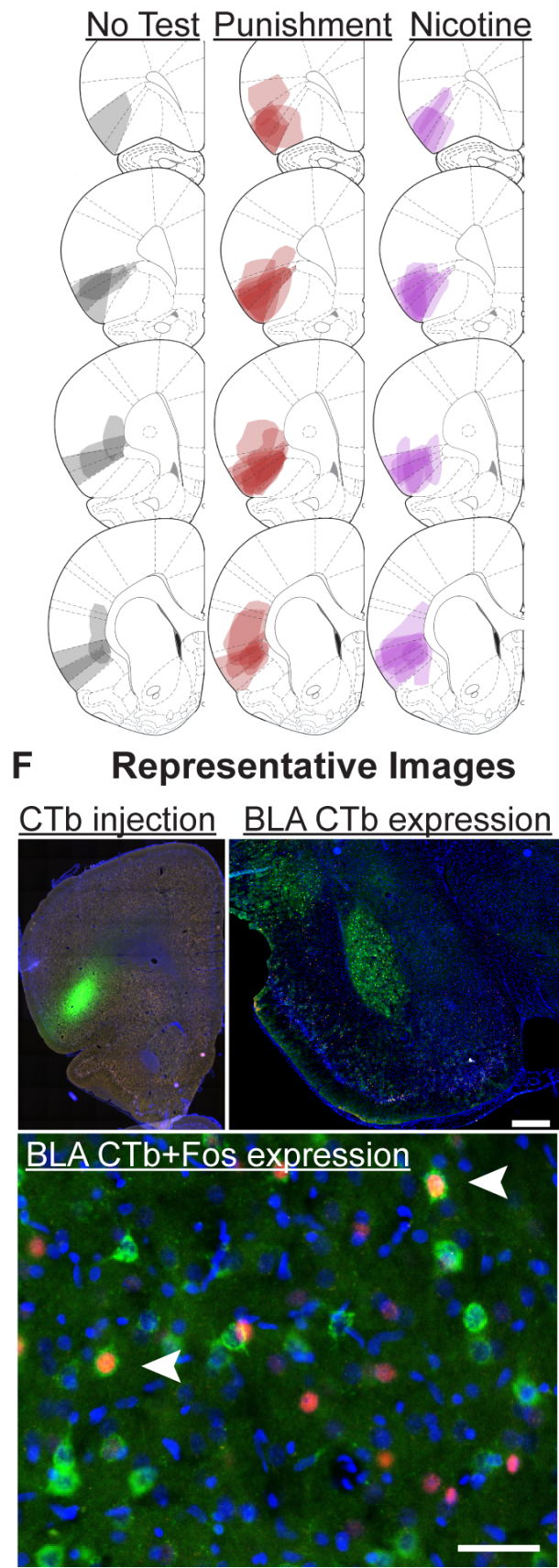

C
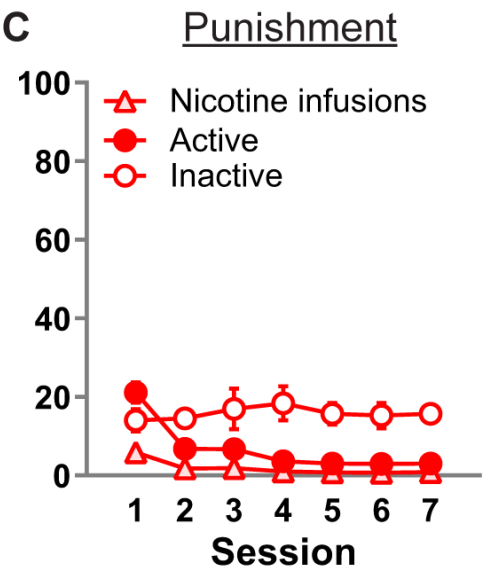

G

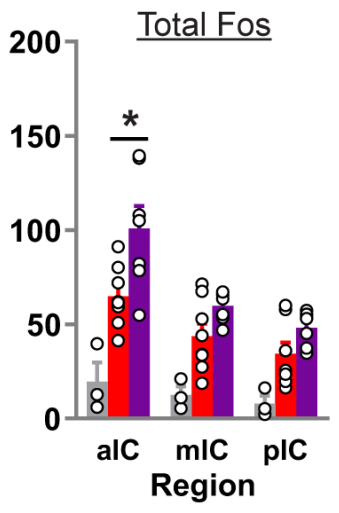

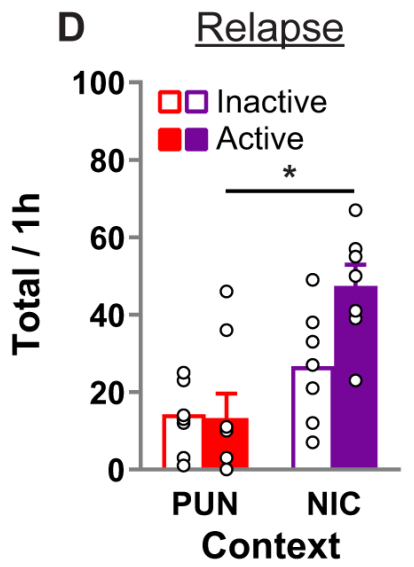

H

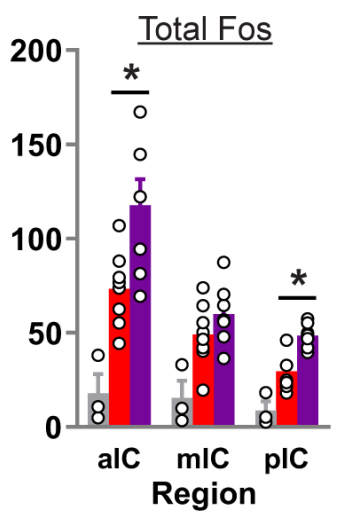

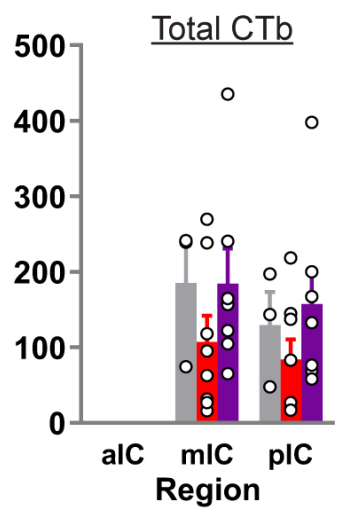

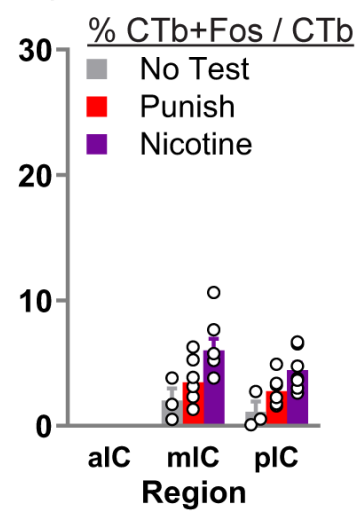

Insula - Contralateral to CTb injection
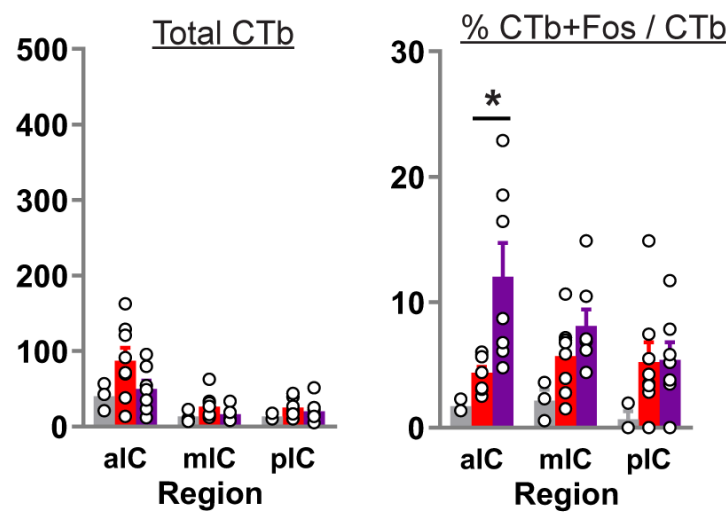

BLA - Ipsilateral to CTb injection
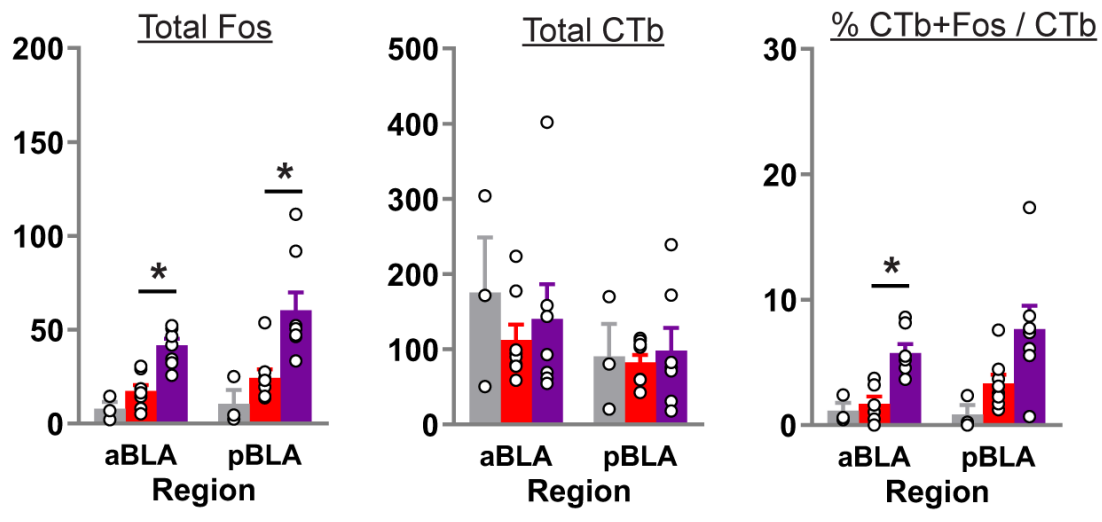
A

Behavioural Procedure

AAV injection

Phase 1:

Phase 2:

Phase 3:

+ Fiber implant jGCaMP7f

Context $A$

$18 \times 1 \mathrm{~h}$ sessions

$30 \mu \mathrm{g} / \mathrm{kg} /$ infusion
Punishment

Context B

4-10 $\times 1$ h sessions

$30 \mu \mathrm{g} / \mathrm{kg} /$ infusion

Response contingent shock

B
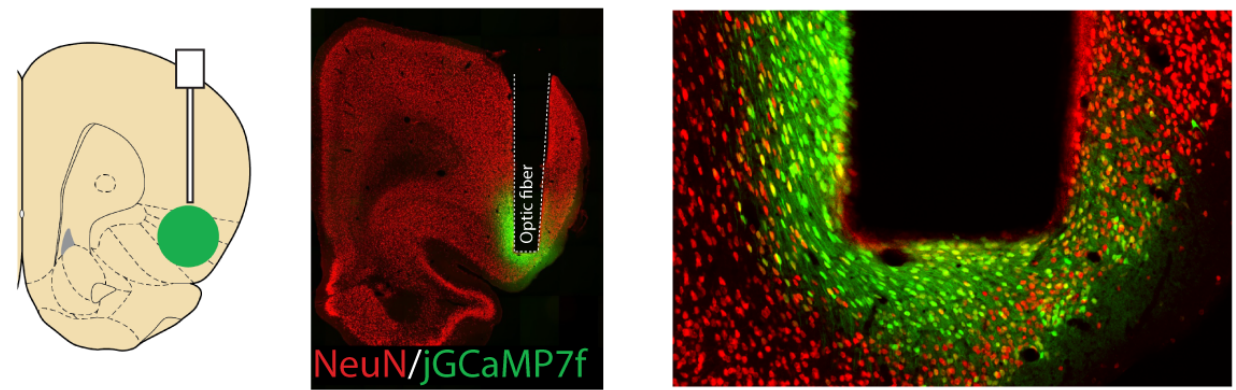

Behaviour

C Nicotine self-administration

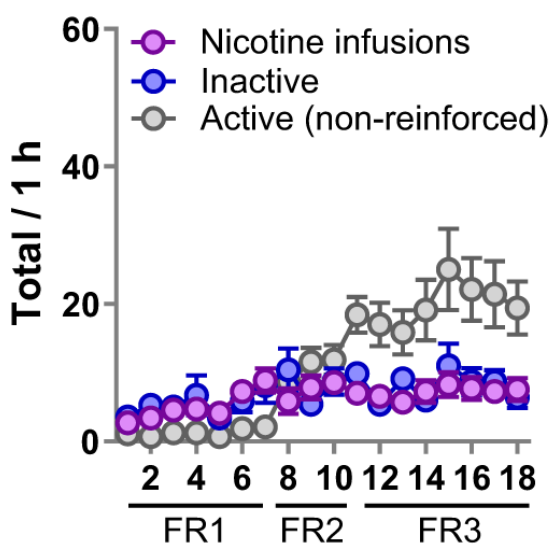

F Nicotine self-administration

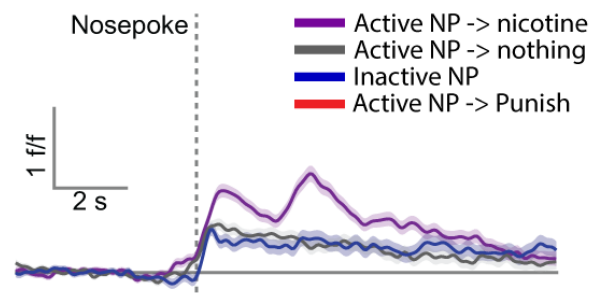

Difference from Baseline

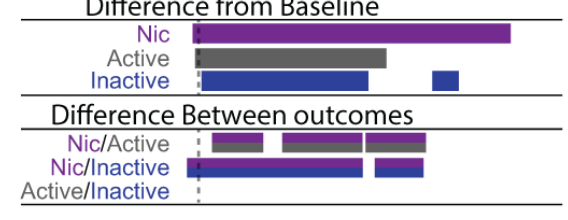

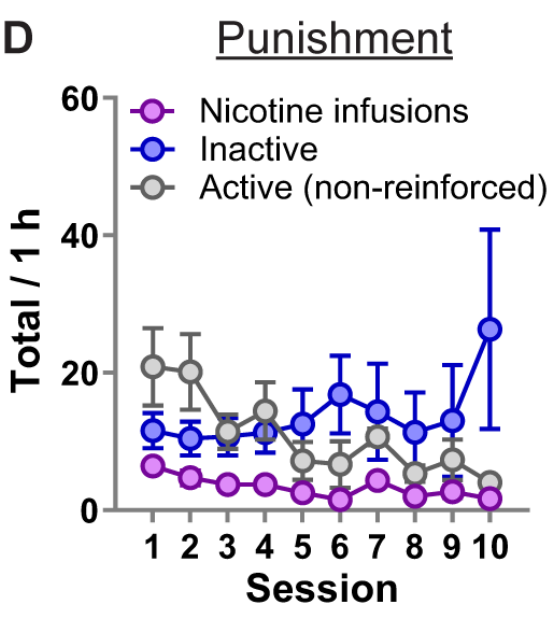

Photometry in alC
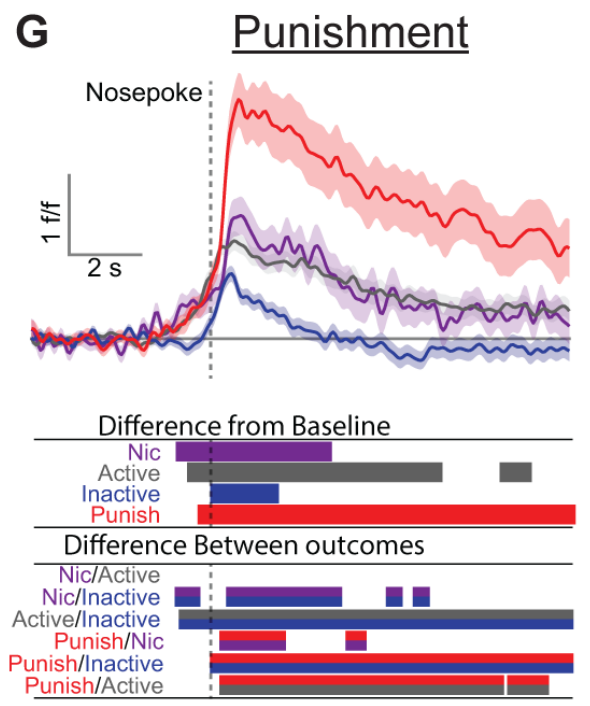
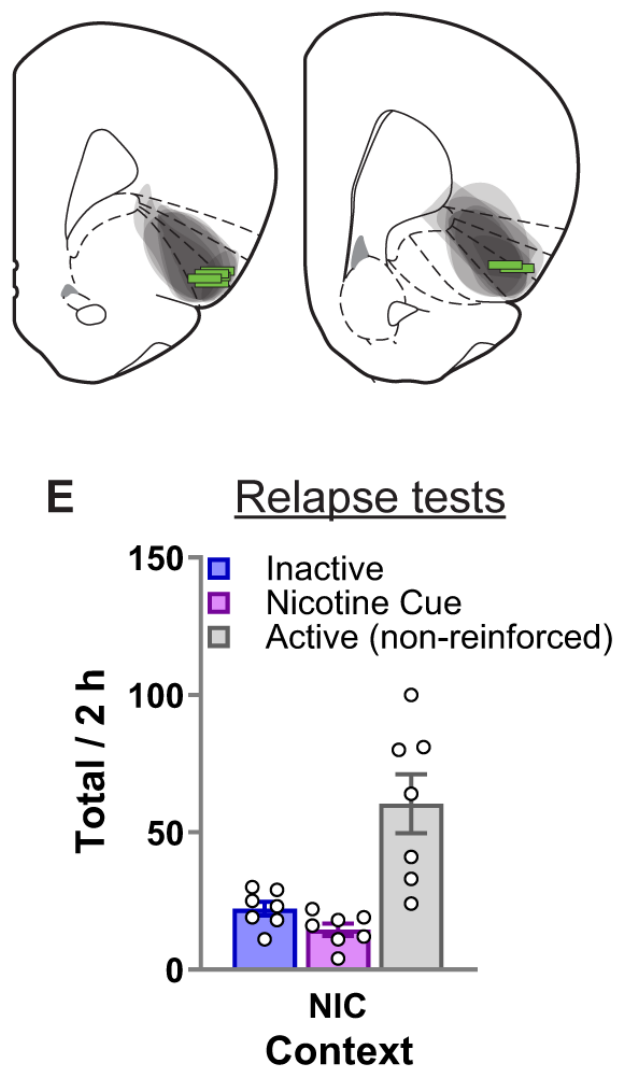

H

\section{$\underline{\text { Relapse tests }}$}
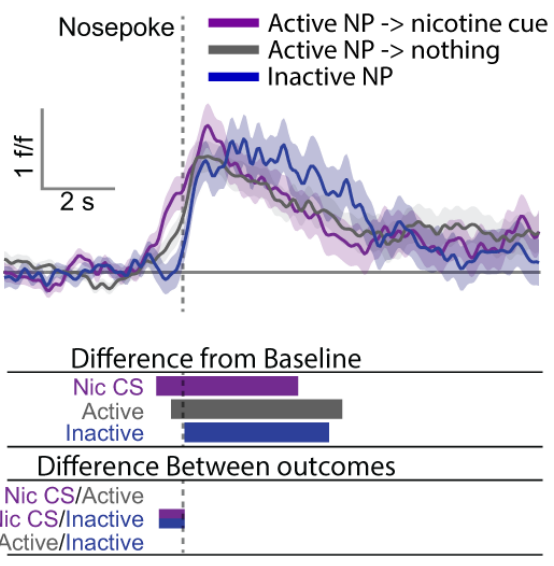


\section{A AAV injections B B Single trace example}

AAV5::CaMKIla::hM4Di::mCitrine

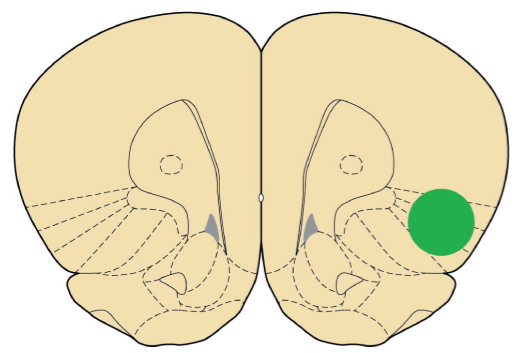

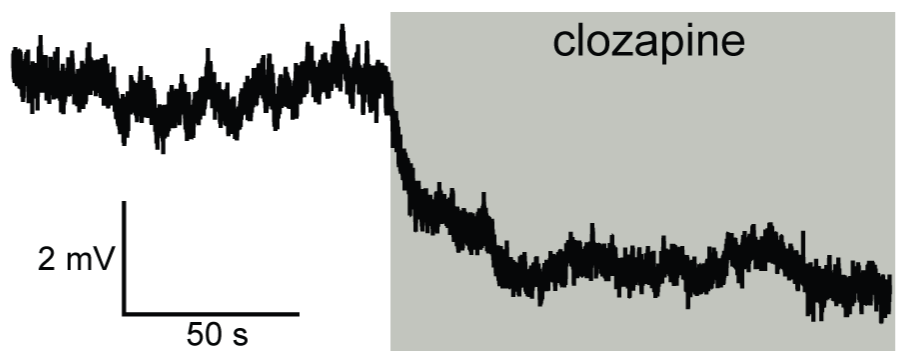

C Mean $(n=6)$

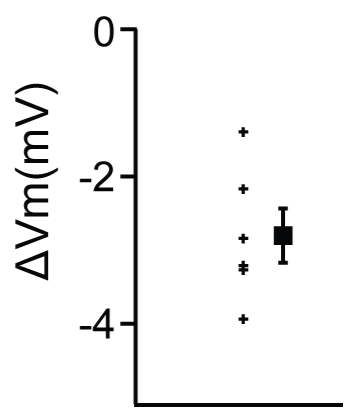




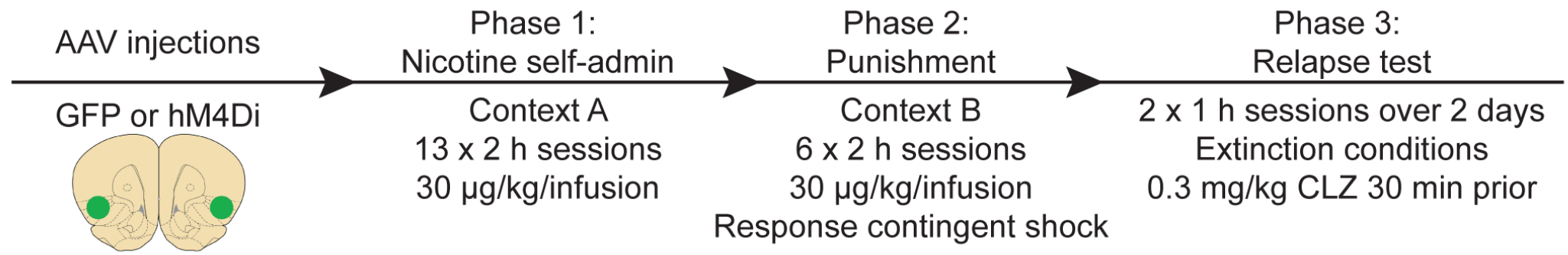

B Nicotine self-administration C

Punishment

D
Relapse tests

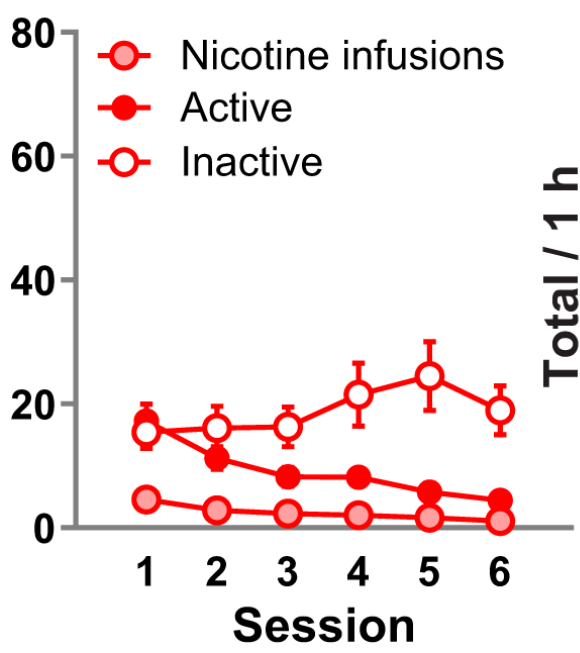

GFP and hM4Di expression

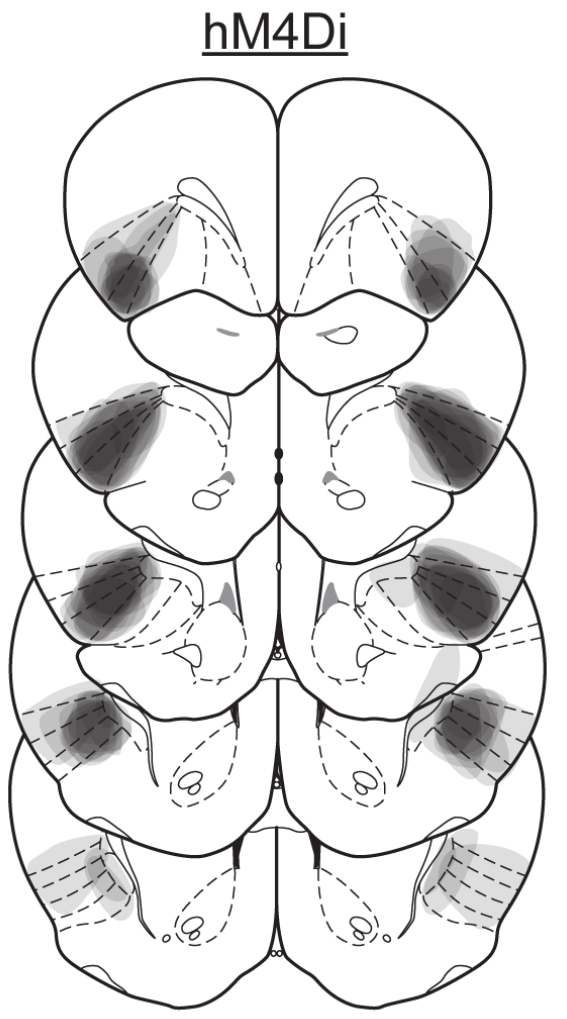
$\underline{\text { Context B }}$

Context A

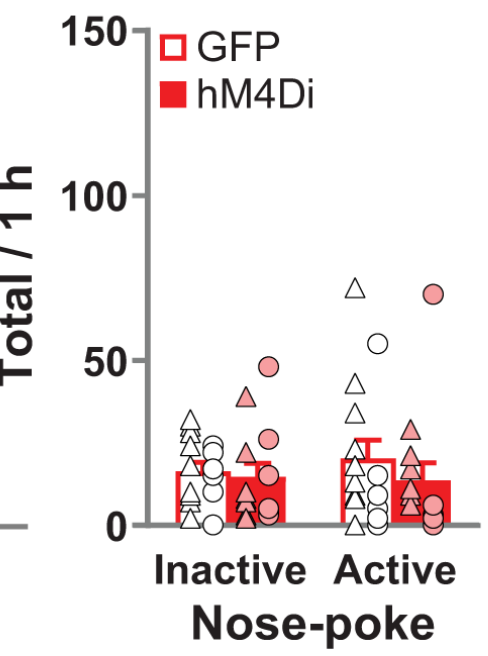

E
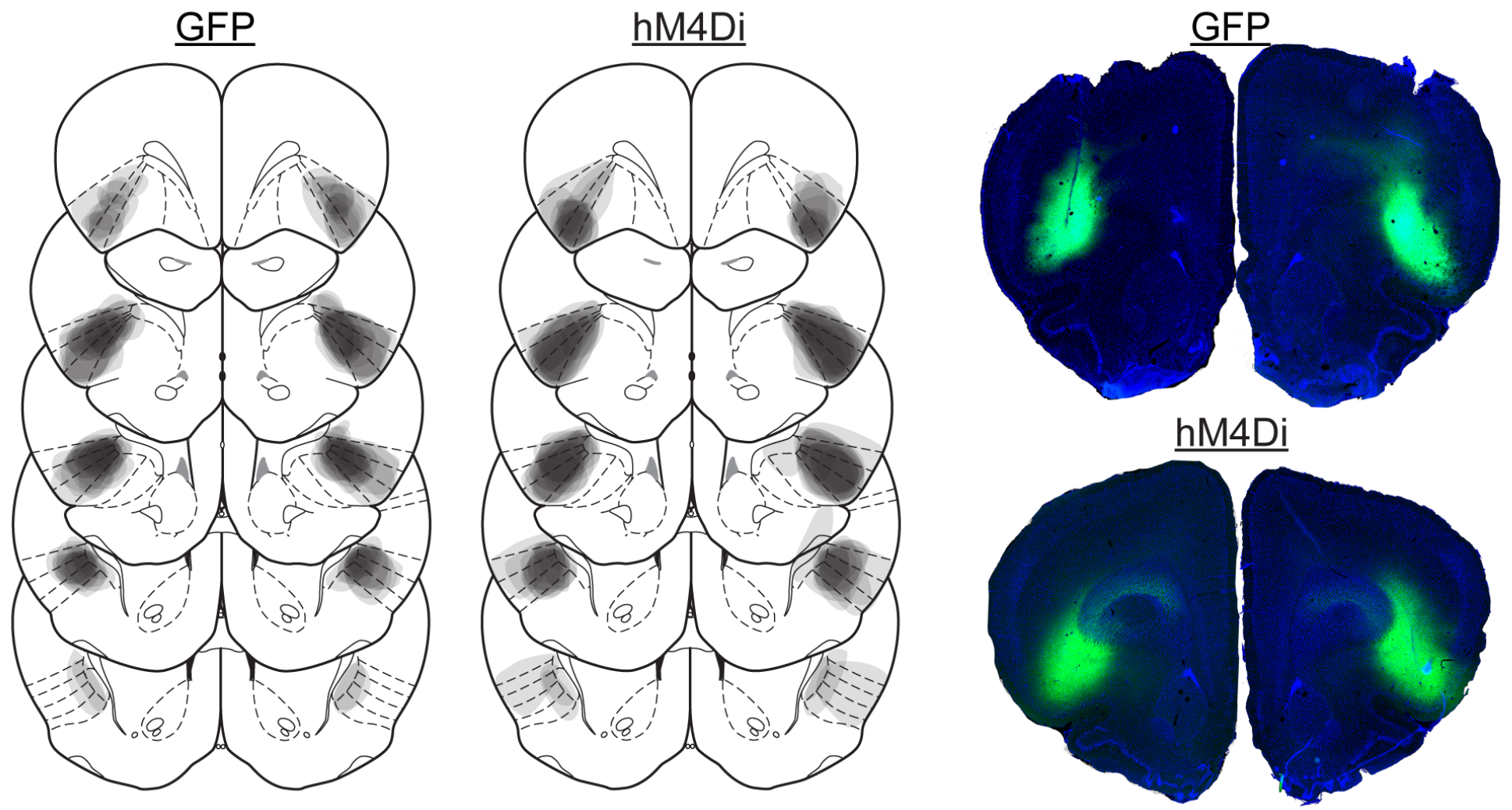


\begin{tabular}{|c|c|c|c|}
\hline AAV injections & $\begin{array}{c}\text { Phase 1: } \\
\text { Nicotine self-admin }\end{array}$ & $\begin{array}{l}\text { Phase 2: } \\
\text { Extinction }\end{array}$ & $\begin{array}{l}\text { Phase 3: } \\
\text { Relapse test }\end{array}$ \\
\hline GFP or hM4Di & Context A & Context B & $2 \times 1$ h sessions over 2 days \\
\hline 0.160 & $\begin{array}{l}13 \times 2 \text { h sessions } \\
30 \mu \mathrm{g} / \mathrm{kg} / \text { infusion }\end{array}$ & $\begin{array}{l}8 \times 2 \text { h sessions } \\
\text { Saline infusion }\end{array}$ & $\begin{array}{c}\text { Extinction conditions } \\
0.3 \mathrm{mg} / \mathrm{kg} \mathrm{CLZ} 30 \mathrm{~min} \text { prior }\end{array}$ \\
\hline
\end{tabular}

B Nicotine self-administration C

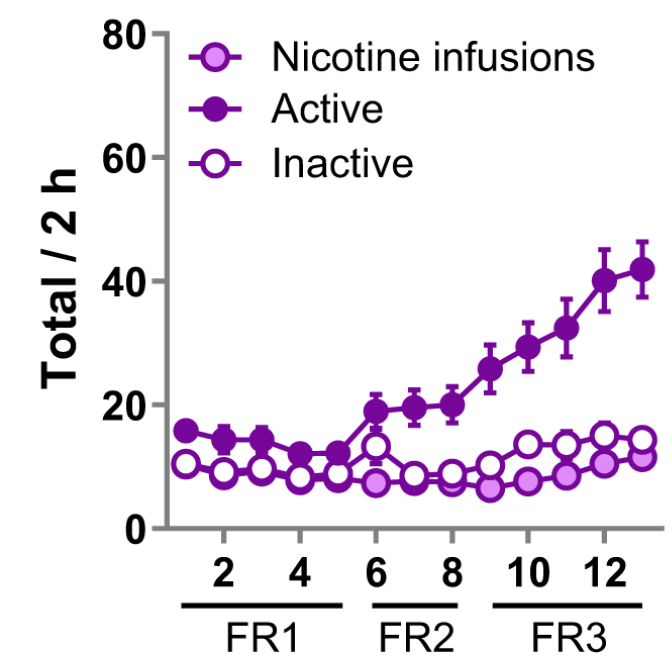

E

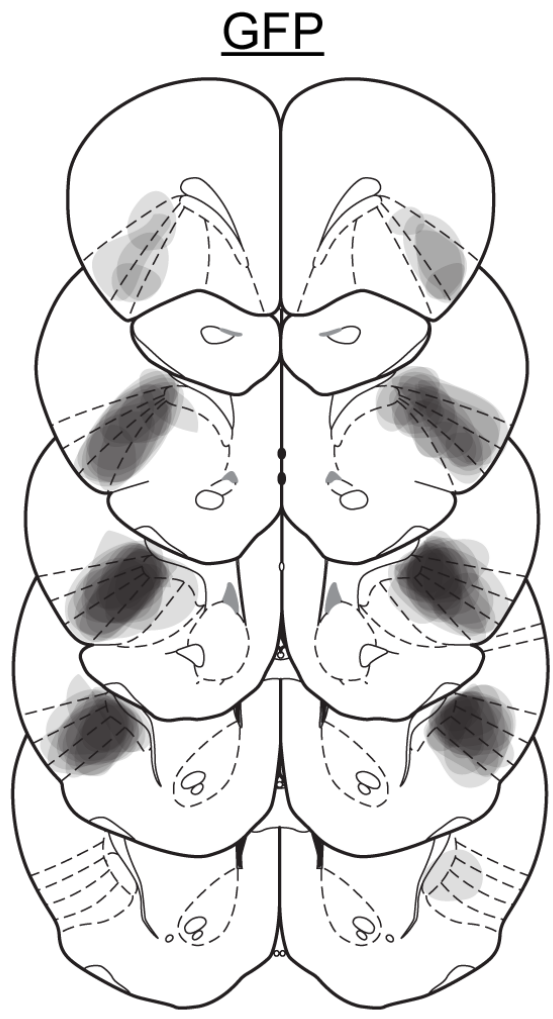

Extinction

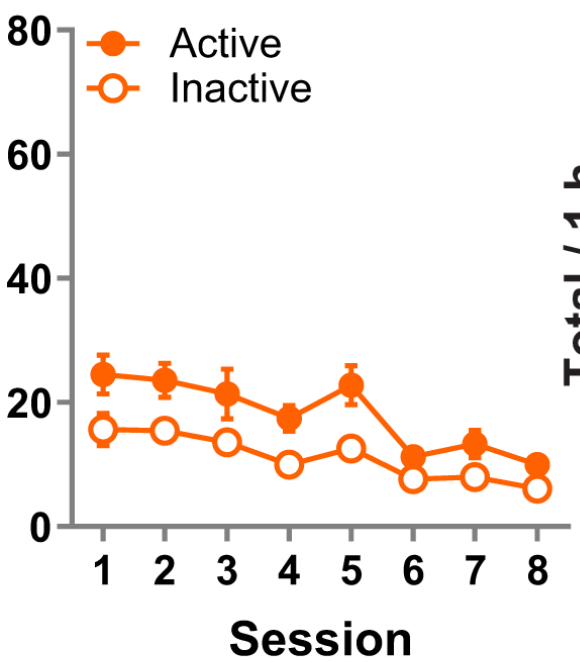

GFP and hM4Di expression

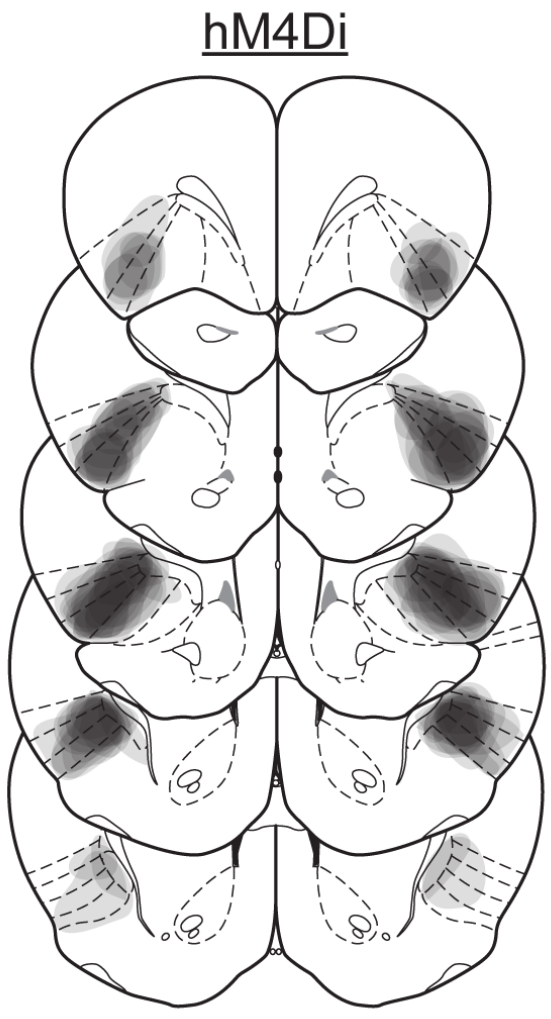

Relapse tests Context B

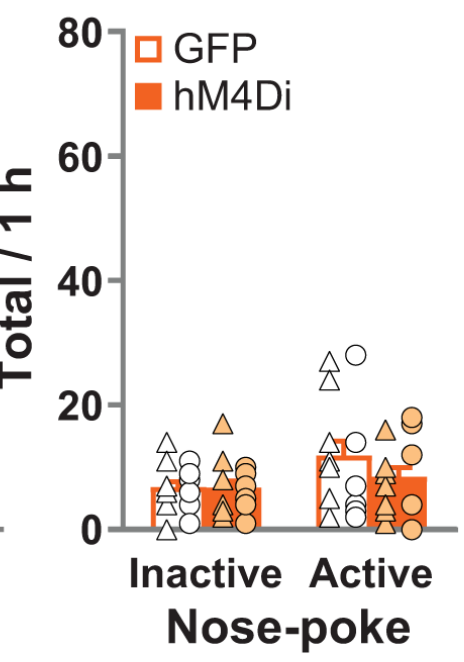

Context A

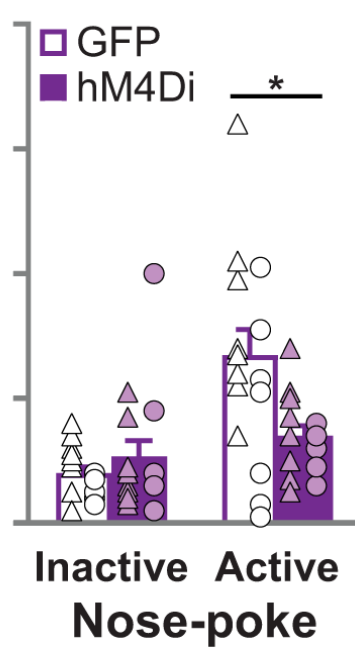

